\title{
The Royal Academy of moral and political sciences and the emergence of social sciences in Spain $(1857-1923)^{1}$
}

La Real Academia de ciencias morales y políticas y el
nacimiento de las ciencias sociales en España (1857-1923)

ELODIE RichaRd

Centre de Recherches Historiques (CNRS-EHESS)

elodie.richard@ehess.fr (FRANCIA)

Recibido: 30.04 .2014

Aceptado: 05.05.2015

\begin{abstract}
This article deals with the emergence of social sciences in Spain at the end of the nineteenth century. It focuses on the Royal Academy of moral and political sciences, whose creation in 1857, on the French model, was part of the reorga-nisation of public education, but also an ideological reaction of the conservative party (partido moderado), which returned to power after the 1854-1956 Revolu-tion. The Academy was officially in charge of propagating the political doctrines of the regime (namely "doctrinaire" liberalism) and of countering socialism at the scientific level. This paper shows the methodological relevance of studying such a multidisciplinary institution in order to grasp simultaneously the plura-listic scientific matrix of the social sciences as well as the political issues that surround them. It analyses the content and the evolution of moral and political sciences between 1857 and 1923 and highlights the multiple factors that played an active role in the emergence of the social sciences: the legacy of former scho-larly disciplines, the impact of the propagation of naturalistic theories during the liberal revolution of 1868, and the critique of liberalism and liberal sciences following the social and political crisis from the 1880s onwards.
\end{abstract}

\footnotetext{
1 Translation : Seema Sarangi Doutrelant.
} 


\section{KEY WORDS}

Moral and political sciences, social sciences, academy, evolutionism, liberalism, organicism.

\section{RESUMEN}

Este artículo examina la cuestión de la institución de las ciencias sociales en España al final del siglo XIX. Lo hace a través del estudio de la Real Academia de ciencias morales y políticas, creada en 1857 según un modelo francés, instrumento de la reforma liberal de la Intrucción pública y de la reacción ideológica del partido moderado despues de la révolution de 1854-1856. La función oficial de la Academia era la difusión de la doctrina política del régimen (el liberalismo doctrinario) y la refutación científica del socialismo. Intentamos demostrar el intérés metodológico de su estudio para conocer las raices disciplinares multiples de las ciencias sociales y los debates políticos que determinaron su institucio-nalización. La evolución de las ciencias morales y politicas entre 1857 y 1923 permite entender los elementos que participaron a la formación de las ciencias sociales : el legado de las disciplinas que les precedieron, el impacto de la difu-sión de las teorías naturalistas (evolucionismo) durante la Revolución de 1868, y la crítica del liberalismo y de las ciencias liberales, enfrentadas a la " cuestión social » a partir de los años 1880 .

\section{PALABRAS CLAVE}

Ciencias morales y políticas, ciencias sociales, academia, evolucionismo, liberalismo, organicismo.

\section{INTRODUCCIÓN}

The emergence of social sciences in the late modern period is a crucial issue for the history of science. The history of science has tended to investigate this question retrospectively, that is, from the disciplines currently classified as social sciences, and usually treats the question within a given national context. In Spain, because of the important role played by "Krausist" lawyers in the institution of social sciences, the history of this process is a subject shared between the history of $\operatorname{law}^{2}$, intellectual history ${ }^{3}$, the history of sociology and

${ }^{2}$ Gil Cremades (1969), Diaz (1973).

3 Nuñez (1975), Gonzalo Capellan de Miguel (2005). 
anthropology $y^{4}$, and the history of social reform ${ }^{5}$. In dealing with the subject, most of these fields focus on the late nineteenth century, commonly regarded as the period of the first institution of the social sciences in Western countries ${ }^{6}$.

However, over the past ten years, historians have stressed the need to study the history of social sciences before they were constituted as disciplines, to investigate the "early history" of their establishment in order to identify the varied factors involved in their emergence. This predisciplinary history of social sciences devotes great attention to the sciences of government ${ }^{7}$. Thus, in the case of France, this history of social sciences has focused in particular on one of its long-forgotten branches: the moral and political sciences ${ }^{8}$. The moral and political sciences were founded at the end of the eighteenth century but disappeared at the end of the nineteenth century when the social sciences were established, surviving only in the name of the Academies which had been created to represent them. The "moral and political sciences" arise from the convergence of different sciences dealing with mankind, human societies, and the laws that regulate these societies. The foundation of the moral and political sciences was the achievement of an enlightened political and intellectual project aimed to combine knowledge and reform mankind and government. This project was implemented under the French Revolution, and was imported in Spain during the liberal revolutions. The moral and political sciences were founded in Spain in 1857 with the creation of the Spanish Royal Academy of moral and political sciences $^{9}$, to which this article is devoted. We intend to stress the methodological relevance of research carried out on this multidisciplinary institution in order to grasp simultaneously the pluralistic scientific matrix of the social sciences and associated emerging political issues. We also intend to emphasize the role played by the local appropriation of foreign knowledge and institutions in this process ${ }^{10}$.

This institution, founded in 1857 on the French model of the "National Academies", was placed at the intersection between science and politics given its status, composition and field of research. Because of the ideological nature of its tasks, it has seldom been examined as an scientific institution ${ }^{11}$. The perception of the Academy as a primarily political organisation devoted to the recognition of liberal elites stems from a traditional notion of scientific activities as neutral. This article rather examines the role of the Academy for what it was in its day: a political and scientific institution, a place for research and for the recognition of

${ }^{4}$ Sánchez Gomez, Ortiz (1994), Del Campo (2001).

${ }^{5}$ Uría (2000), Zarco (1999).

${ }^{6}$ Wagner (1991).

7 Schiera, P. (1991), Napoli (2003), Laborier, P, Napoli, P, Vogel, J., Audren, F., (2011).

${ }^{8}$ Heilbron (2004 : 145-157), Heilbron, Magnusson, Wittrock (1998 : pp. 3-5), Vincent (2007 : 38-43).

${ }^{9}$ It sums up some conclusions of the thesis that I defended in 2008. See Élodie Richard, L'esprit des lois. Droit et sciences sociales à l'Académie royale des sciences morales et politiques d'Espagne (1857-1923), University of Paris 1-Sorbonne, 2008.

${ }_{10}$ Heilbron,. Guilhot, Jeanpierre, L. (2009/2).

${ }^{11}$ It is most often studied in the context of the history of political ideas. The works of Antón Mellon (1989), Cerezo Galán (2002), Diego García (2009) are examples. 
scholars. From a methodological point of view, studying the Academy offers the opportunity to assemble a coherent corpus of texts and their authors, documents related to their activities, readings, debates and political uses of their theoretical work. These sources enable us to forego a pure textual analysis of canonical texts for the benefit of a social, cultural and political history of scientific knowledge. The study of these texts in a given setting, over a medium length but a crucial period, allows us to observe the evolution of the moral and political sciences and thus to produce a detailed chronology of their history. It underlines the continuity between the late XVIII ${ }^{\text {th }}$ and XIX ${ }^{\text {th }}$ centuries in the process of the emergence of the social sciences ${ }^{12}$. Moreover, it helps us to highlight an important change in the 1890s when new subjects, methods, and disciplines as well as new definitions of the natural and social man were being incorporated into the moral and political sciences. This change coincided with the generalization of the term "social sciences." This article illustrates how the study of the institution helps to define precisely the content of the "moral and political sciences", its subjects, methods, anthropology and social and political philosophy. It describes the evolution of this content from 1857 to 1923 , emphasizing the different mechanisms which played an active role in the emergence of the social sciences. This article also covers the legacy of the disciplines that preceded them in the science of man and society (law and Political Economy in particular); and the impact of the propagation of naturalistic theories on the moral and political sciences, after the liberal revolution of 1868, which introduced the free expression of ideas; the introduction of evolutionary sociology into the Academy and finally the shift in the hierarchies of sciences related to the critique of liberal law and political economy from the 1890s onwards.

\section{THE EPISTEMOLOGY AND IDEOLOGY OF THE MORAL AND POLITICAL SCIENCES}

\subsection{The French model: the academic institution of Moral and Political Sciences under liberal revolutions}

The Spanish Academy of moral and political sciences was founded by the $9^{\text {th }}$ September 1857 Act, known as the "ley Moyano", which aimed to reform public education $^{13}$. From an institutional point of view, the Spanish Academy emulated the French model of National Academies, imported into Spain in the eighteenth century by the Bourbon dynasty as part of a monarchical policy of encouragement and control of scholarly activity ${ }^{14}$. In France, this academic system was abolished by the 1793 National Convention but restored in 1795 as

12 Blanckaert (1999: 46).

13 Ley de Instrucción pública, Título IV, art. 160. Viñao Frago (1982 : 379-380), Peset, Peset (1974 : 461-479).

14 Aguilar Piñal (1985 : 152), Velasco Moreno (2000 : 45-46). 
the Institut national des sciences et des arts. This was the framework of the first official institution of "moral and political sciences". During the second half of the eighteenth century, the term "moral and political sciences" became popular through the economic theories of the Physiocrats who defined these sciences as "the principles of moral and political order, natural law and social laws" 15 . They divided the moral and political sciences into three main branches: natural law, social law and the law of Nations, respectively defined as the study of rights and duties of human beings as individuals, as members of a political society and the study of the relations between nations ${ }^{16}$. This term prevailed during the Revolution, most probably under the influence of Condorcet, to denote this "second class" of knowledge alongside physics and mathematics (the first class) and arts and literature (the third class) within the Institut de France ${ }^{17}$. This classification order broke with the Ancien Régime's old hierarachy of knowledge that prevailed in national academies. It asserted the primacy of physical sciences and defined the study of man as a "science"18. Although the second class was suppressed by the first Consul Napoléon Bonaparte (1803), it was re-established in 1835 as the Royal Academy of moral and political sciences with the return of a liberal regime under the July Monarchy (18301848) ${ }^{19}$. The Spanish Academy of moral and political sciences, established twenty years later, was directly influenced by this model ${ }^{20}$. Its creation was part of the State building project implemented by the liberal regime in the $1830 \mathrm{~s}$ and the 1840s, during the reign of Queen Isabel $\mathrm{II}^{21}$. This went hand in hand with the reorganization of public education and the establishment of a higher learning curriculum in administrative sciences assigned to rationalize public action $^{22}$. It was also part of the political context: the Academy was created by a conservative government that returned to power after the 1854 Revolution and the two-year liberal government (bienio progresista) ${ }^{23}$. The Moyano Act was enacted a few months after the Nocedal Printing Act (Ley de Imprenta) ${ }^{24}$. It reinforced the Church's control over public education ${ }^{25}$. Created to supplement

15 It appeared for the first time in the title of the Physiocratic school's publication, "Bibliothèque raisonnée des sciences morales et politiques", Damamme (1995 : 5-30), Weulersse (1910 : 127).

16 Baudeau (1767 : 3-30), Dammame (2006: 3).

17 Leterrier (1995: 6-16), Baker (1975: 316-317).

18 Heilbron (2006: 172-173).

19 Staum (1980: 383-384), Leterrier (1995: pp. 61-71).

20 The project for the establishment of an Academy of Moral and Political Sciences appears for the first time in the Quintana report on public education (1813), which was inspired by the Condorcet report (1792). The moral and political sciences were also represented in a section of liberal scientific society, the Ateneo Científico, Literario y Artístico de Madrid (founded in 1835). Peset Reig, J.L. Peset Reig, M. (1992: 23), Villacorta Baños (2003 : 419).

${ }^{21}$ Charle, Schriewer, Wagner, (2004 :19), López-Ocón Cabrera (2006 : 316-17), Moral Ruiz, Pro Ruiz, Suarez Bilbao (2007 : 243-281).

22 Puelles Benítez (1995), Baena del Alcázar (1997 : 145-160).

23 Gómez Ochoa (2003 : 135-168), Burdiel (2010 : 488-575).

24 The Nocedal Act of 13th July1857. Castro Alfín (1998 : 83-96).

25 Heredia Soriano (1982: 303-307). 
measures of censorship, the Academy was officially in charge of the production and propagation of the political doctrines of the regime ("doctrinaire" liberalism) and scientifically countering socialist proposals. This was achieved through the publication of dissertations or essays which were awarded in annual contests and through the assessment of works whose authors had appealed for State funding for printing and publishing. The Academy also acted as an advisor to the government by writing reports on reform projects and by its representation in the monarchy's Councils ${ }^{26}$. This combination of functions (advising, censorship, and erudition) were quite similar to those of the Academia de la historia in the XVIII $^{\text {th }}$ century ${ }^{27}$.

\subsection{The scientific profile of the academicians}

To understand the significance of the "moral and political sciences" in the period they were established, we can look at how the scholars themselves defined these sciences. A year after the establishment of the Academy of Exact, Natural and Physical Sciences (1847), Antonio Cavanilles, in a note addressed to the Academy of History, described moral science as complementary to natural science:

"When the national Convention created, for the whole Republic, an Institute responsible for collecting all discoveries and for improving arts and sciences (...), it placed the moral and political sciences close to those of physics and mathematics. Beside the first ones, which have been recognized at all times as sciences, the only ones to have so far been given this title, and which, by their brightness, have enlightened all the aspects of men's work and their fight against matter, the Convention proclaimed the existence of these sciences which considered man himself or as a member of society, which taught him to understand his nature and his purpose, his history and laws, to improve his political regimes and better his condition. These sciences, which only 100 years ago were not at all considered as such, are philosophy, morals, law, political economy and general history" 28 .

The creation of two academies of science, one devoted to the "ciencias exactas, fisicas y naturales" (1847), and the other to the "ciencias morales y políticas" (1857) is contemporary with the removal of their teaching from the Faculty of Letters (Moyano Act 1857). The wish was to establish a real "science" of man, but separated from the science of nature ${ }^{29}$. However, this general definition neither enables us to understand precisely the epistemological orientations which unify this branch of knowledge, nor to grasp the historical

26 The Junta consultiva de Instrucción Pública (from 1871), the Consejo penitenciario (1881)

27 Velasco Moreno (2000 : 217).

28 Academia de la Historia. Archivo Cabanilles, legajos 41 y 52, Academias (Historia y ciencias morales y políticas), "Opusculos publicados por la ASMP". The hand-written note allows us to set the date to 1848 .

${ }^{29}$ Peset Reig, Peset Reig (1992 : p 17), (1974: 683-684), Peset, Garma, Perez Garzón (1978). 
significance of its foundation. That is why studying the Academy is useful. In so doing we can examine objectively its scientific content from several indicators: the scientific profile of the academicians and the themes and content of their academic works. If nomination or election to a seat in the Academy can be considered as the recognition of a skill, the profile of the academicians may then be interpreted as an indicator of the official significance attributed to the moral and political sciences by their founders: first of all, the government, which made the first nominations, then the other academicians who thereafter controlled the composition of the institution via cooptation. This profile can be observed in the biographical materials about the academicians, produced by the institution itself in investiture speeches or obituaries. The investiture speeches, which determined access to the Academy, gave the new members the opportunity to prove their scientific skills. At the same time, the academicians welcoming the new members on behalf of the academic corps had the chance to justify their election. These sources help us to build a typology of the knowledge incorporated within the institution. Five profiles can be identified amongst the 86 academicians appointed or elected between 1857 and $1889^{30}$ : university professors, law practitioners, administrators, politicians and clergymen. During this period, $18 \%$ of the academicians elected were university professors. The majority (13 out of 15) held chairs at the Faculty of Law in the Universidad Central of Madrid; these chairs were often connected to the new "administration" department in which political economy was taught ${ }^{31}$. In addition to law professors, the Academy had welcomed a physician, Felipe Monlau, Chair of Public Health (Higiene Pública), and a literature professor, Marcelino Menéndez y Pelayo. (The Public Health chair had been affiliated with the faculty of medicine since 1843.) Reviewing the applications which were rejected during the constitutive assemblies, we find that two university disciplines, philosophy and history, could have been represented. It was indeed for political reasons that the historian Emilio Castelar ${ }^{32}$ and Julian Sanz del Río, professor of philosophy of law, had been excluded from the institution. The former had sided with the democrats during the Revolution (1854). The latter, Sanz del Río, had introduced the pantheist theories of the German philosopher Karl Krause in Spain and had translated the works of one of his disciples, the lawyer Heinrich Ahrens, whose classes he had attended at the Université libre de Bruxelles in the 1840s. His criticisms of the 1857 Act on Public Education in the name of the secularization of education cost him his nomination to the Academy ${ }^{33}$.

30 All the elected Academicians are included and not only those who actually took their seats.

31 Public and Administrative Law (Manuel Colmeiro, Laureano Figuerola), Philosophy of Law (Pedro Sabau), History of treaties and International trade relations (José Moreno Nieto, Eugenio Moreno López), Spanish Codes (Benito Gutiérrez), Canon Law (Joaquín Aguirre, Eugenio Montero Ríos, Francisco Gómez Salazar), Ecclesiastical Discipline (Juan Antonio Andonaégui), Science of Public finances (Victor Arnau), Political Economy (Santiago Diego Madrazo, Melchor Salvá).

32 Chair of "philosophical and critical history of Spain" in 1858

33 Capellán de Miguel (2003:185). 
Members of the Academy of History, such as Modesto Lafuente and Antonio Cavanilles, rival authors of the first national histories, represented the discipline of history at the Academy ${ }^{34}$. The second academic profile is that of lawyers and magistrates known for their doctrinal works or for their involvement in commissions responsible for law codification, such as Pedro Gómez de la Serna or Francisco Cárdenas. The third category comprised administrators (such as Alejandro Mon, José García Barzanallana), specialists in public finance, tax law, the electoral system, demographic or agricultural issues (for example, Fermín Caballero and Alejandro Oliván, both members of the Statistical Commission of the Kingdom, founded in 1856). Moreover, the Academy reserved a number of seats for clergymen, a particularly Spanish feature ${ }^{35}$. It also welcomed diplomats, career politicians, party leaders and historical figures of the liberal revolutions (e.g. Antonio Alcalá Galiano) ${ }^{36}$. Thus, the Academy assembled not only the representatives of academic disciplines such as law, economics, theology and history but also practical knowledge holders recognized for their administrative skills, political activity or experience in the courts. An examination of the academic profiles also shows that the moral and political sciences included not only an overwhelming majority of lawyers, but also economists whose influence in the institution was stronger than at the university ${ }^{37}$.

\subsection{The social and political philosophy of the Academy}

These academicians gathered each week to "cultivate the moral and political sciences". They engaged in several types of activities: collecting documents (setting up a library, exchanging information with relevant scientific institutions), promoting works (organizing contests, allocating State grants for publication) and holding meetings for collective reflection on readings and discussions. These highly codified discussions were an essential activity in the Academies, created historically against the scholastic university model to allow specialists direct exchanges with peers ${ }^{38}$. The examination of the themes developed in individual dissertations, the discussions and the questions submitted to the contests enable us to produce a classification of the main subjects of the moral and political sciences between 1857 and 1890 .

\footnotetext{
34 Pellistrandi (1997: 148).

35 Six clergymen were elected and appointed at the Academy whereas the academicians in the French Academy were secular, Staum (1980 : 375), Delmas (2006 : 16).

36 Salustiano de Olózaga, the leader of the Progressive Party, elected in 1857, as well as the moderates Pedro José Pidal and Claudio Moyano (1857), the conservatives Antonio Cánovas del Castillo (1871), and Francisco Silvela (1886) and Alejandro Pidal y Mon (Unión Católica, 1878).

37 Manuel Colmeiro, Laureano Figuerola, Eugenio Moreno López, Santiago Diego Madrazo, Melchor Salvá taught this discipline in the Universities.

38 Waquet (2003: 252-262).
} 


\section{Thematic classification of academic works (1857-1889)}

\section{Civil Law}

Individual rights, ownership rules, family law (successional law, marriage).

Individual rights, ownership rules, family law (successional law, marriage).

\section{Penal law and penitentiary system}

Royal pardon, prison reform, deportation penalty.

\section{Public law and political theory}

Suffrage, representative government, organization of justice, municipal government, socialism, revolution, equality and freedom.

\section{Political economy and public finance}

Economic theories, taxation, currency, trade policy, price, economic development (agriculture, industry, savings).

\section{Populations and territory administration}

Supplies and food, population density, emigration, conscripts' height, work (accidents, slavery), Public education (compulsory education, clergy and co-education), poverty, charity. Opinion, journalism and censorship (theatre), religious movements and relationships between Church and State.

\section{International Law}

Colonization (America, Morocco, Caroline Islands), International law (extradition, internationalism), diplomatic relations.

\section{Moral and political sciences}

Biographies of statesmen and scientists, social and political theories (positivism, utilitarianism).

A detailed review of the content of debates, competitions and official reports enables us to identify an "academic doctrine", developed collectively and hammered out during heated discussions. Despite theoretical differences among the arguments, it is nevertheless possible to speak of a single "doctrine" thanks to the procedures adopted for the publication of these works. Although Article 43 of the Academy's statutes maintained the principle of academicians responsibility for their own publications, they still were subject to collective control. Dissertations, reports and investiture speeches were not published before having been read and approved by peers. These works thus reflected the opinion of the institution not because it was unanimous, but because it was the result of a vote which imposed the dominant view of the majority. This doctrine was dependent on the scientific and political orientation of the active members and their relation with the government. In the first decade of its existence (1857-1868), the Academy was politically close to the dominant Moderate 
Party. This party had created the Academy and made sure it maintained control by appointing the heads of its main currents to academicians' seats and making its leader, Pedro José Pidal, president of the Academy. The mechanism of cooptation extended the effect of the first nominations on the political composition of the institution for a long time. This meant that the left wing of liberalism (the Progressive party) was underrepresented and the opponents of the regime (Democrats) were excluded or put in a tiny minority (Carlists).

Academic works provided scientific backing to the doctrinaire ideology of the regime and defended the representative form of government - without universal suffrage - and the guarantee of individual freedom, except in religious matters ${ }^{39}$. The Academy also grasped the issue of modernizing Spain, defined in the terms of the liberal theory, a "liberal Mercantilism" 40 which were largely inherited from the analyses the Enlightenment reformers had provided one century earlier ${ }^{41}$. This indeed raised the issue of national unity, jeopardized as it was by the disparities in population and land ownership regimes, and by the divergence of economic interests between the different provinces. It also investigated the historical and structural causes of the backwardness of Spanish economy, especially in agriculture. In order to solve these problems, the Academy recommended the modernization and unification of civil law, the "encouragement" of rural settlement, the redistribution of land ownership and state reforms of Public Education and prisons. But it was divided on the issue of free trade which caused both a scientific and political split in the institution $^{42}$. Adhering to the French liberal school and the Progressive party, the economists (Manuel Colmeiro, Laureano Figuerola) were indeed in favor of trade liberalization ${ }^{43}$. On the contrary, protectionist academicians were often former administrators (Claudio Moyano et Florencio Rodríguez Vaamonde) who shared a mercantilist vision of the economy, and were sensitive to the arguments of the German historical school of economics (Friedrich List) ${ }^{44}$. In the academic works ${ }^{45}$, the discourse on man and human societies was developed either in general terms ("man", "mankind", "people") or through legal or social status ("single", "married", "unmarried", "natural children", "nobility", "producer", "intellectual profession", "farmer" "landlord/owner") or even through civil,

39 Díez del Corral (1945), Romeo Mateo (1998 : 2-12).

40 Lluch (1996 : 164).

41 Especially Jovellanos (1744-1811) often quoted in academic works and in particular in the following reports: Informe sobre la influencia del teatro en las costumbres públicas, (1860) Informe sobre la reforma de las leyes de inquilinato (1863) Rodríguez Vaamonde (1874).

42 De la conveniencia o inconveniencia de la libertad de comercio atendidas las actuales condiciones de España (1859-1860).

43 Members of pressure groups in favor of free trade and the abolition of slavery, they encouraged the Academy to subscribe to the Journal des Economistes. Lluch Martín, Almenar Palau, (2000-135-143).

44 Lindenfeld (1997: 151-154).

45 This list is drawn from the study of 48 papers, reports and discussions presented at the Academy between 1860 and 1889 and put together in the volumes III, IV and V of the Academy's Memorias. 
political and economic institutions ("government", "parliament", "municipal councils", "Church", "judiciary", "state", "guilds", "family". The only social empirical data used by the academicians came from statistics on populations or from history, especially from the history of law which incorporated ethnographic material $^{46}$. This inventory of terms and scales used to describe human societies shows that the moral and political sciences tended to grasp them mainly through the abstract categories defined by law and economics. It also shows that their proposals were often derived from legislation and intellectual authorities, as well as general considerations on human nature.

\subsection{A spiritualist anthropology}

In doing so, the moral and political sciences did not seem to differentiate themselves from the administrative sciences introduced in higher education in the $1840 \mathrm{~s}^{47}$. These sciences embraced knowledge and disciplines that were established in the eighteenth century ${ }^{48}$. In Germany, where they had been early introduced in university teaching to train the administrators of the emerging states, they were grouped under the name of "cameral sciences" 49 . These sciences embraced the "good government" political theory, the information on territorial resources, including population, the study of public finances and governing skills in the areas of public intervention ("Polizei") such as education, health, and religion. As the management of human affairs (and not human societies themselves) remained their primary focus, the academic moral and political sciences seemed to deviate from their original definition as a "science of mankind" or "science of man in society". It is necessary to interpret this difference: was it indicative of a preferential "cameral" orientation of the Spanish moral and political sciences, related to the scientific profiles of the academicians (most of whom were lawyers and administrators) ${ }^{50}$ ? Or did it reveal more deeply the difficulty subsisting in the middle of the nineteenth century to take social facts as research subjects? In order to answer this question, it is important to go back to the roots of the moral and political sciences in natural law and check the definition of man and human societies the academicians provided in the introduction to their treatises on law and economy. These books, like the treatises on natural law $^{51}$, began with a definition of nature and purpose of man (conceived as universal and immutable) as well as a description of the origins of civil society. The handbook of public law published by the professor Manuel Colmeiro in 1855 provides a good example.

\footnotetext{
46 Alonso Martínez (1875).

47 Baena del Alcázar (1997).

48 Peset, Peset (1974 : 292-301).

49 Tribe (1984 : 263-284), Laborier (1999).

50 Walker (1978 : 234-240).

51 Kelley (1990 : 217).
} 
"Chapter I. The destiny of man

While creating man, God endowed him with a mortal body and an immortal soul. Spirit and matter are both part of human nature, a double bond that unites it with this visible world and future life, which is the end of our pilgrimage on earth $(\S 1)$ ".

"Chapter II. Civil Society

Reason and history teach us that the family was born first; then the meeting of several families formed the tribe; and then, all the different tribes formed the people, and then later, through the aggregation of peoples, the nation or state appeared, all this under the influence of the powerful laws of nature which apply to man without any agreement or arbitrary covenant (\$3)"'52.

On the origins of civil society, the interpretation of liberal law differed from the ones natural law had developed one century earlier ${ }^{53}$. These are not addressed here on a philosophical mode and in contractualist terms but as historical and organic realities consistent with the scholastic conceptions of the birth of political societies ${ }^{54}$. Thus, man and society themselves were not the subject of a specific investigation because their nature was from the outset predefined $^{55}$. The moral and political sciences derived their principles from this definition, which conferred a special status on man in nature. Man was indeed described as the only creature on earth endowed with a rational spirit in conformity with Christian anthropology. This characteristic placed him partly outside nature, which explains why the moral and political sciences were systematically conceived as separate from and complementary to physical and natural sciences ${ }^{56}$. As for the combination between moral philosophy and science of government on which the unity of the title "moral and political sciences" was founded, it stemmed from the postulate of man's natural sociability and his necessary belonging to various communities whose different scales (the family, the city, the state) laid the foundations of the internal subdivisions of the science of man (morals, economics, politics, international law). The subject of moral and political sciences is rather man's "actions" than man himself, man as a moral being who, according to law theoreticians, obeys rules, and thereby distinguishes himself from other creatures, whose behavior is determined by nature ${ }^{57}$. When the moral and political sciences were first founded in France (1795), they were defined in a larger sense in accordance with the content the Encyclopedists had given to "the science of man", which included morals and

52 Colmeiro (1863:5-6).

${ }^{53}$ Foucault (1966: 329-346).

${ }^{54}$ The doctrinaire liberalism endorses the criticisms made by the counter-revolutionary writers against the theories of the social contract, concerning their anthropological abstraction and their political implications, Nisbet (1944: 319).

${ }_{55}$ Smith (1995: 96-97), Blanckaert (1999: 35-46).

${ }^{56}$ Descola (2005 : 102-118).

57 Pufendorf (1672: 3). 
$\operatorname{logic}{ }^{58}$. In the second class of the Institut de France, the first section was named "analysis of sensations and ideas", which helps us understand that this institution included the science of cognition (psychology, logic), defining it according to the sensualist approach ${ }^{59}$. Although this synthesis was made possible by the success of the naturalistic paradigm in European sciences at the end of the eighteenth century $^{60}$, it disappeared with the new academic division within scientific knowledge which prevailed at the beginning of the following century ${ }^{61}$. The restoration of the moral and political sciences under the July Monarchy took place at a time when spiritualist philosophy (Victor Cousin) was intellectually and institutionally dominant, excluding any physiological approach to mental processes at the Academy ${ }^{62}$. This spiritualist definition of moral and political sciences imposed itself on the Spanish Academy. The presence of theologians and the absence of physicians and philosophers amongst its members reinforced this orientation ${ }^{63}$.

\subsection{The boundary between Moral and Political Sciences and Natural Sciences}

This definition of man had implications on the range of sciences seen as moral and political ones: anthropology, the science of natural man, was excluded as was the medical study of psychological processes. Moreover, the boundaries of moral and political sciences were problematic in two areas of study: theology, conceived as the study of God; and economics, the science of wealth, devoted to the study of man's relation to matter. For the traditionalist wing of the Academy, the presence of theology among the moral and political sciences guaranteed by the election of several clergymen fulfilled two requirements. In institutional terms, it brought the study of canon law into this field of knowledge, and on a theoretical level, it completed the official monitoring of the moral and political sciences by guaranteeing that their proposals did not cross the borders which separated faith from science ${ }^{64}$. The other scientific discipline whose inclusion in the moral and political sciences posed a problem was political economy, as shown by the concern of its representatives to defend it in their writings and investiture speeches, which during that period were the only ones strictly devoted to a specific scientific field ${ }^{65}$. These argumentative pleas revealed the reticence aroused by this new science in an academic world dominated by lawyers. The critiques of political economy indeed expressed a corporatist

\footnotetext{
58 J. D'Alembert (1763, $1894: 167)$.

59 Staum (1980: 373), Moravia (1974).

60 Blanckaert (2002: 145), Chappey (2006: 44).

61 Heilbron (2006: 167-180).

62 Leterrier, (1995: 64).

63 Except the hygienist Felipe Monlau, who died before his reception at the Academy.

64 Santiago de Tejada (1860), Miguel Sanz Lafuente (1860).

65 Figuerola (1861), Pastor (1863), Madrazo (1864).
} 
reaction against its supposed ambition of unifying all the branches of the science of man and serving as an exclusive guide for public policy ${ }^{66}$. This fear was based on the superiority of its claim to be a science capable of setting out laws ("i.e. law of supply and demand"). On a deeper level, the rejection of political economy had ideological reasons related to the system of values that liberal political economy had inherited from the Enlightenment period and which nourished its critical approach to law (anti-legalism, plea for natural law against conservatism and the erring of positive law ${ }^{67}$. This conservative critique was expressed in terms of a moral condemnation. Firstly, it denounced the egotism of the science of "wealth" and "self-interest". It also condemned the materialistic attitude political economy showed by only focusing on the physical reality and material needs of man.

\section{POLITICAL AND SCIENTIFIC REVOLUTIONS}

\subsection{The 1868 Revolution and the reception of Evolutionism in Spain}

This separation from the natural sciences which contributed to the definition of the moral and political sciences itself was subverted in the 1870 s in Spain by the propagation of evolutionist and materialist theories developed within the framework of natural sciences. This spread was made possible by the establishment, after the liberal Revolution in 1868, of a regime which encouraged the freedom of religion, of expression and education; and encouraged the wide translation and review of foreign works ${ }^{68}$. Darwin's works On the Origin of Species (1859) and The Descent of Man (1871) and those of Ernst Haeckel, the German materialist philosopher and biologist, were translated at this time ${ }^{69}$. In a confessional country, attached to the control of scientific discourse and its conformity with Catholic dogma, the effects of this epistemological break were felt beyond a strictly scientific field. The Church opposed the spread of naturalist theories because they contradicted the biblical account of the origin of life and man's place in creation ${ }^{70}$. The first government of the Restoration (1875) tried to put an end to this by reestablishing censorship and state control on education, thus causing an academic crisis and another intellectual controversy over "Spanish science" $(1876)^{71}$. The conflict was initiated by the Catholic writer Marcelino Menéndez y Pelayo, who defended the superiority of a national catholic science against an impious form of science which was rooted in Protestant Northern Europe. These attacks were aimed at a group of faculty members who identified themselves symptomatically

\footnotetext{
66 Benavides, in Pastor (1863: 144).

67 Epsztein (1966 : 103-122), Vatin (2006/3).

68 Nuñez Ruiz (1975: 165-175), Sala Catalá (1987- 23-32).

69 Pelayo (1999: 135-144; 290-299), Nuñez Ruiz (1969 : 24-31).

70 Pelayo (1999: 307-340).

71 Hermida de Blas (2011 : 23-29).
} 
with "Krausists", a non-native school of thinkers" ${ }^{72}$ The Krausists were the disciples of Julian Sanz del Río, who contributed to the propagation in the Spanish Universities of a German pantheist philosophy, which rejected dualist theories that placed God outside nature ${ }^{73}$. The Spanish Krausists made Krause's work, judged of minor importance in its own country, the foundation stone of a liberal philosophy of law open to naturalist theories, but also the starting point of a republican political commitment in favour of religious liberty and of the secularization of education and scientific progress ${ }^{74}$.

\subsection{The neo-thomist critique of scientific positivism: the metaphysical basis of moral and political sciences}

This controversy found an echo in the Academy's debates. During the first public session celebrated under the Restoration, the liberal lawyer Manuel Alonso Martínez made a speech entitled "The development of religious ideas in Europe. Presentation and critique of the Krausist system"75. In this speech, he criticized the strictly philosophical approach to religion proposed by the Krausists who defined it as an intimate relationship between man and God, of which Catholicism would only be one of the possible forms. Martínez also criticized their pantheism, which he identified with materialist positivism, as did the defenders of the Church. The historians of Krausism have shown that these criticisms blamed this metaphysical and idealistic philosophy with a positivism which was alien to it $^{76}$. We can however understand these criticisms because of the role played by Krausism in the defense of the freedom of speech which authorized its propagation, but also because this pantheist philosophy was very responsive to the doctrines which tend to blur the separation between mind and nature ${ }^{77}$. In the 1870 s and 1880 s, the Academy continued to be an important place for the criticism of positivism and its applications to the moral and political sciences for two main reasons: firstly, because the Revolution swung the institution into a conservative opposition to the liberal and republican governments which followed one another between 1868 and 1875 . It was indeed mainly composed of moderates (appointed for life), who were hostile to the government's economic and judicial reform programme as well as to its social reforms. The participation of some of its members (Ríos Rosas, Figuerola, Aguilar y Correa, Olózaga) in this Revolution was certainly the cause of the resignation of its president, Lorenzo Arrazola, on $1^{\text {st }}$ December $1868^{78}$. This conservative trend increased in the 1880 s because of the election of

\footnotetext{
72 Nieto Blanco (2011 : 82-94), Capellán de Miguel (1999/1 : 162).

73 Orden Jiménez (1998).

74 Capellán de Miguel (1998: 137-153).

75 Alonso Martínez (1876).

76 Capellán de Miguel (2006 : 222-235).

77 Simó Ruescas (2004).

78 Libro de actas, 1868
} 
academicians belonging to the conservative party of Antonio Cánovas which had been instrumental in the Restoration of $1875^{79}$. The disappearance of progressive academicians elected in the 1860s made Figuerola, a liberal and then republican economist, the last radical figure of the institution.

The second reason for the Academy's commitment to the critique of scientific positivism was based on the fact that its split with the government and the end of censorship modified the conditions for the exercise of its ideological functions. Until then responsible for consecrating and spreading the official policy of the government, from a hegemonic position, it had to make its differences of opinion known from then on, through a wider propagation of its works. In 1870, to this purpose, it decided to authorize the publication of its proceedings (discussions, papers, reports) and to use the contests it organized to take a stand in public debates ${ }^{80}$. Finally, the academic refutation of naturalist positivism could not be separated from that of socialism, whose propagation in Spain was also the result of the freedom of publication and association and called into question the fundamental principles of the moral and political sciences: private property and the family as the foundation of society ${ }^{81}$. This can be observed in two "extraordinary" contests which were launched by the Academy in the 1870s and were explicitly intended to encourage the demonstration, firstly of the impossibility of Communism (1872), secondly the absence of conflict between science and the Catholic religion $(1878)^{82}$. The other medium of propagation of this critique were the speeches given by the new academicians at the time of their investiture in the institution ${ }^{83}$. These members provided the framework of a real anti-naturalist apology, due to the election of the main Spanish representatives of neo-Thomism, a philosophical movement formally appointed by the Pope to fight naturalist and materialist hypotheses ${ }^{84}$. By being open to rational reasoning and to a scientific approach, and including a reflection on matter, Thomism offered a credible alternative to positivism to which it opposed a dualist conception of the world. Ceferino González, the Cardinal Archbishop of Seville, a pioneer of the revival of Thomistic studies in Spain ${ }^{85}$, who had a keen interest in natural science, was elected in 1873 to join the Academy, which thus rewarded him for his contribution to the refutation of Darwinism, assimilated with positive materialism within the Academy.

79 In the $1880 \mathrm{~s}$, seven of the 13 academicians elected were former conservative ministers.

${ }^{80}$ Libro de Actas, 22nd February 1870.

81 Termes (2000: 31-47), Piqueras Arenas (1992: 119-170).

82 This contest was designed to encourage the refutation of John William Draper's History of the Conflicts Between Religion and Science (1874), the translation of which had sparked in 1876 the controversy over Spanish science.

83 Caminero y Muñoz (1881), Perier y Gallego (1881), Fr. González (1883), Pidal y Mon, A. (1887), Mena y Zorrilla (1892).

${ }^{84}$ McCool (1994), Capellán de Miguel (1999 : 417- 448).

85 Forment (1998: 19-21). 


\subsection{The rejection of sociology and experimental psychology}

This critique was not the prerogative of theologians and catholic authors. It also involved eminent liberal politicians, who were concerned about the emergence of a positivist social science and its political implications in the 1880s. The positivist epistemology of natural sciences indeed developed a monistic approach to reality that did not separate man from nature. It thus allowed the inclusion of man and society in the naturalists' field of study and enabled them to transfer their lexicon and theories to the science of man; organicist and evolutionary sociology, the first systematizations of which took place in the 1870s, developed from these conceptual and methodological exchanges $^{86}$. This epistemological split also contributed to the shifting of psychology towards natural sciences, as shown by the birth of experimental psychology ${ }^{87}$. In Spain, the introduction of these new disciplines took place outside the universities, especially in the Institución Libre de Enseñanza (the Free Institution of Education) founded by Krausist professors excluded from universities during the crisis of $1876^{88}$. Most of them were reinstated in universities in 1881 by a liberal government that also restored freedom of education. The same year, Cánovas del Castillo, the outgoing president of the government, entered the Academy with a speech warning against the threat that naturalistic theories presented for the moral and political sciences. Naturalism did indeed give birth to a new science, that of sociology. Sociology dealt with the traditional subject of "man himself and the society in which he lives", but ignored the metaphysical foundations of the moral and political sciences. Cánovas' intention was thus to defend the "true social science", against sociology, "this arrogant doctrine which enters our home like a new owner, knocking at every door" $"$. Based on a naturalistic conception of the social world, sociology indeed rejected the divine origin of society, the existence of reason and morality as exclusive attributes of man and reflections of a moral law given by God. It contested thus not only the moral and political sciences' spiritualist anthropology, but by its determinism it also undermined the principles of liberal economy and penal law, such as the notions of "interest" and "individual responsibility". This discourse reflected a shift in the critique formulated by naturalistic theories. They threatened not only Catholic dogma but also the very foundations of the moral and political sciences. In 1883, the Academician Alonso Martínez decided to defend these sciences on hostile ground by agreeing to give lectures in the Institución Libre de Enseñanza. The academic dissertation explicitly presented itself as a text to fight against Comte's positivism, which

86 Guillo (2000 : 295-319), Vatin (2005 : 123-217).

87 Lafuente Niño (1980), Carpintero, Lafuente Niño (1996).

88 The teaching of sociology and experimental psychology was introduced in the Institución Libre de Enseñanza in 1881 and 1877 (respectively) and in the other Universities in 1898 and 1902. Cacho Viu (1962).

89 Cánovas del Castillo (1881). 
was made necessary by the context of freedom of expression ${ }^{90}$.

\subsection{Comte vs. Spencer}

This critique was addressed primarily towards Auguste Comte's political project to establish an authoritarian social organization and a "cult of humanity" judged by Alonso Martínez to be sacrilegious. More profoundly, Comte's philosophy of knowledge was the target of this critique, which was very broadly based on the refutation proposed by Herbert Spencer in an essay in which he opposed point by point his own philosophical system (Synthetic Philosophy) to that of Comte's (Positive Philosophy) ${ }^{91}$. Alonso Martinez reproduced this opposition built by Spencer in a strategy of self-differentiation against a rival ${ }^{92}$, at a time when his own work was gaining huge popularity in Europe ${ }^{93}$. The motives of this paradoxical agreement with the proposals of a renowned agnostic and radical author need to be clarified because they are one of the keys which enable us to understand the acceptance of sociology in the Academy. The choice of Spencer against Comte indicated the desire to modernize the moral and political sciences but without jeopardizing their political and epistemological foundations. Spencer's theory of evolution saw the issue of the origin of organic beings as fundamental, while it appeared secondary in Comte's view. Spencer did not deny the existence of God or the idea of a "first cause", assuming only its "unknowable" character. Applying the law of evolution to all the levels of reality, this theory accounted for the genesis and progress of human societies ${ }^{94}$. This progress was embodied in a typology of social forms and institutions corresponding to the stages of a linear development. In the 1880s, this historical dimension of Spencerian sociology made academicians forget its naturalistic roots, as shown by the tendency of academicians to classify Spencer's work in the familiar field of the philosophy of history or that of moral philosophy ${ }^{95}$. As a dynamic version of the social organicism that flourished in that period, this sociology defended the individualism of different social organs and the notion of self-interest, being thus compatible with the liberal conception of society ${ }^{96}$. But more importantly, Spencer, like most of the English philosophers, including positivists, admitted the possibility of a scientific psychology, unlike Comte who rejected it from his classification of knowledge, for the benefit of phrenology ${ }^{97}$. For Alonso Martínez, who thought that every philosophical system must be based on the Cartesian "cogito", this was a significant point. Comte's

\footnotetext{
90 Alonso Martínez (1883)

91 Spencer, Reasons for Dissenting from the Philosophy of M. Comte (1864).

92 Becquemont (2003 : 61-65), Bourdeau (2003).

93 Becquemont, Muchielli, (1998), Ramírez Arlandi (2007 : 284-290), Beltrán (2004 : 230).

94 Peel (1992:131-191).

95 Fermín Lasala y Collado, Duque de Mandas (1882).

96 Monerero Pérez (2009).

97 Petit (2002), Clauzade (2003).
} 
rejection of a subjective science of the human spirit swept away the idea that the fundamental principles of the moral and political sciences could have been placed by God in men's consciousness. The compatibility of the Spencerian system with the moral and political sciences was also due to methodological reasons. In fact, this system, which grounds itself in "primary principles", is less in contradiction with these deductive and prescriptive sciences than the positivist epistemology, the real drawback of which, according to Alonso Martínez, was to say only "what there is and not what there should be"98. Moreover, in his rejection of any affiliations with Comte, Spencer proclaimed himself to be the heir of an ancient English tradition which owed nothing to positivism.

\subsection{Conservatism, Historicism and the development of empirical investigations}

Thus the rejection of sociology in the Academy was also achieved through the claim for an empirical method, specific to the moral and political sciences. That was the meaning of the investiture speech of the academician Luis Pidal y Mon in 1889, who praised the "social science" of Le Play, a science based on survey and devoted to social reforms of a Catholic orientation ${ }^{99}$. In this speech he denied positivism the monopoly and paternity of the empirical method, pointing out what it owed to the German school of the history of law and to the critical history of the French Revolution ${ }^{100}$. As the Catholic leader of a conservative party (la Unión católica), Luis Pidal y Mon perpetuated the ideological historicism supported by the most conservative wing of the Academy since the 1860 s and in particular by the neo-catholic Santiago de Tejada. In his academic memoirs ${ }^{101}$, Tejada criticized the granting of legislative power to elected assemblies and defended the "historical rights" whose genesis he described as the spontaneous expression of the spirit of people, according to the romantic conception of law dominant in German legal theory of the early nineteenth century. On a scientific level, this counter-revolutionary speech expressed itself by the defense of the history of law, the empirical study of judicial institutions, as a response to the supposed idealism of the Enlightenment's anthropology, which made the abstract individual of natural law the vector of unlimited rights ${ }^{102}$. The history of law was already being practiced at the Academy because its members were involved in the process of codifying civil law ${ }^{103}$. But this "genre" underwent great development in the years following the revolution of 1868, because it provided the arguments for a scientific critique of liberal reforms of marriage and ownership (secularization of

\footnotetext{
98 Alonso Martínez (1883: 397).

99 Pidal y Mon, L. (1887). Savoye (1999).

100 On the spreading of the history school of law in Spain see Cremades (1969).

101 Tejada (1862), (1863), (1865).

102 Kelley (1990: 242).

103 Clavero (1982), Tomás y Valiente (1989 : 94-95).
} 
marriage, agrarian reform) ${ }^{104}$. Several lawyers of the Academy such as Francisco Cárdenas and Alonso Martínez endeavored to demonstrate the antiquity, the universality and therefore the necessity of private ownership and family founded on the sacrament of marriage ${ }^{105}$. Placed between the philosophy of law and the comparative history of judicial institutions, these works provided the framework to set out a theory of the genesis of society conceived of as an aggregation of families. In liberal public law treatises, this historicized version of Aristotelian and then scholastic conceptions of the birth of society allowed their authors to describe political institutions such as the city, the nation or the state as kinship groups whose evolution was that of an organic growth. This development of the history of law and the favorable reception of Spencerian evolutionism largely explained the epistemological split that affected the moral and political sciences in the $1890 \mathrm{~s}$.

\section{SOCIOLOGY'S ENTRY INTO THE ACADEMY AND THE ADVENT OF SOCIAL SCIENCES}

\subsection{The evolution of academic profiles}

These splits can be observed in the evolution of the academicians' scientific profiles and in the subjects of academic reflection. Significant changes can indeed be observed through a prosopographical study of the academicians elected from 1890 to 1923, that is to say for a period of 33 years, and a fixed number (86) of academicians, similar to the ones we have examined for the previous period. The first change was the increase in the number of university professors, which went up from $30 \%$ to $35 \%$, and the considerable decrease in former ministers whose numbers fell from half to a quarter of the elected members ${ }^{106}$. Even though the "dual" scientific and political profiles of the academicians remained a constant ${ }^{107}$, these changes indicated however the swing of the institution towards a more clearly scientific status. The second change concerned the disciplines which the moral and political sciences grouped together. Although the academicians in their majority (81\%) were trained lawyers, we notice changes in the lectures given by the professors who were elected to the Academy. On the one hand, canon law and ecclesiastical history disappeared and on the other hand, philosophy ${ }^{108}$ was introduced, as well as a new discipline, sociology, with the election of Manuel Sales y Ferré in 1905, the first holder of this new chair, which was established in 1898 in

104 Baro Pazos (1992 : 181-190), Serrano García (2006).

105 Cardenas, de (1870), Alonso Martínez (1875).

106 The number of clergymen remained stable (six).

107 As seen by the large proportion of Academicians (72\%) who had seats in the Parliament.

108 Taught by University professors (Juan Manuel Ortí y Lara, José Ortega y Gasset, Adolfo Bonilla) or ecclesiastical seminaries (Zaragüeta y Bengoechea, Arnáiz Calvo). The Academy also appointed a professor of Arabic, Miguel Asín y Palacios. 
the University of Madrid. The Academy went on welcoming professors of economy and law but with new areas of concentration within these disciplines, as the title of their chairs tells us. The Academy from then onwards appointed a specialist of "natural law" (Francisco Javier de Castejón y Elío) for whom a chair was introduced in 1883 by the neo-Thomists in order to counter the spread of Krausist positivism in law faculties ${ }^{109}$, but also law historians such as Rafael Ureña and Rafael Altamira, and a professor of comparative municipal law such as Adolfo Posada and Adolfo Buylla, a professor of social economy. The introduction of new disciplines expanded the range of subjects taken up by the Academy. From 1890 onwards, works dedicated to "social issues" increased in number to a point where they represented around one quarter of the discussions during that period and whose proportion increased twofold in the subjects of the contests. Until then, social issues had been considered within the classical framework of a reflection on the causes of poverty, of the organization of charity or of rural ownership. From then on, the condition of the working class, strikes, the spread of socialism and social legislation became matters of interest for the academicians. The other notable innovation was the interest of the academicians in sociological methods and theories, for "society" and "social facts".

\subsection{Krausist lawyers and the introduction of sociology in the Academy}

Between the 1880s, when a radical critique of sociology was rampant at the Academy, and the year 1905 when it recruited a sociologist, the 1890s marked a crucial period in the recognition of this discipline. Three academicians played a vital role in legitimizing sociology: the Krausist professors of law, Gumersindo de Azcárate and Vicente Santamaría de Paredes and the publicist Eduardo Sanz y Escartín, who were elected to enter the Academy in 1889, 1891 and 1893 respectively. Azcárate and Santamaría de Paredes were coopted at the Academy by the liberal camp as can be seen in the nomination proposals made by the academicians recorded in the book of proceedings ${ }^{110}$. At that time, the Krausists were no longer a marginal school but a united group of intellectuals trying to acquire institutional positions at the university and who dominated the teaching of law ${ }^{111}$. Sanz y Escartín could be said to have a foot in both camps. As a PhD in Literature, he failed in 1880 to obtain a chair in psychology and became a librarian at the Senate ${ }^{112}$. He was a reader of Spencer and Maudsley, a disciple of the economist Piernas y Hurtado, a Krausist professor. But he owed his election to the Academy to the conservative camp ${ }^{113}$. This election rewarded

109 Gil Cremades (1969: 188-189).

110 The nomination of Azcárate was also proposed by Figuerola (4th March1890) and that of Santamaría de Paredes by Colmeiro and Antonio Aguilar y Correa, Marquis de la Vega de Armijo (3 February 1891).

111 Pérez Prendes (1999).

112 Dietrich, de (1898), Necrología del Excmo Sr. D. José Piernas y Hurtado (1912).

113 His nomination was proposed by the Count of Casa Valencia, Juan de la Concha Castañeda 
him for two books: one on social issues and the other on worker protection; both books were influenced by social Catholicism and the German historical school of economics and were officially recommended by the ecclesiastical hierarchy ${ }^{114}$. These three men introduced sociology into the Academy at a time when its definition had not yet been stabilized, and even its status as a science was a controversial issue. They overcame the reluctance of the Academy endeavoring to explain sociological theories, relying in particular on two foreign journals: The Quarterly Review and La revue philosophique de la France et de l'étranger. They contributed to bringing the sociology professor Sales y Ferré into the Academy, the French sociologist René Worms (as a correspondent) as well as lawyers and economists who were then considered as sociologists ${ }^{115}$. The election of a new academician was based on cooptation. New candidates could only be put forward by members of the Academy and were then elected via a vote, in which only active members could take part (that is to say, those who had attended the number of imposed academic meetings in the previous year). As can be observed from the records of nominations, the election of Krausist sociologists was the cumulative result of the Krausist investment in the Academy.

and the Count of Torreanaz (Libros de Actas, 28 mars 1893).

114 Sanz y Escartín (1890), (1893).

115 We have drawn up this list from the authors mentioned as such in the first Spanish theoretical treatise of sociology, Principios de Sociología, published in 1908 by Adolfo Posada, and from the Spanish authors who published articles between 1896 and 1906, in the French journal edited by Durkheim, L'année sociologique. Rafael Altamira, Adolfo Álvarez Buylla, Adolfo González Posada taught sociology at the Faculty of law of Oviedo from 1895. 


\begin{tabular}{|c|c|c|}
\hline Date & $\begin{array}{l}\text { Candidates proposed } \\
\text { and elected }\end{array}$ & Proposals made by \\
\hline $19^{\text {th }}$ February 1895 & Joaquín Costa & $\begin{array}{l}\text { Azcárate, Francisco Silvela, } \\
\text { Menendez y Pelayo }\end{array}$ \\
\hline 28 $8^{\text {th }}$ April 1896 & $\begin{array}{l}\text { René Worms } \\
\text { (correspondent) }\end{array}$ & Figuerola, Sanz y Escartín \\
\hline $12^{\text {th }}$ March 1903 & $\begin{array}{l}\text { José Manuel Piernas y } \\
\text { Hurtado }\end{array}$ & $\begin{array}{l}\text { Azcárate, Sánchez de Toca, } \\
\text { Fernández Villaverde }\end{array}$ \\
\hline $17^{\text {th }}$ October 1905 & Manuel Sales y Ferré & $\begin{array}{l}\text { Azcárate, Sanz y Escartín, Piernas } \\
\text { y Hurtado }\end{array}$ \\
\hline $8^{\text {th }}$ May 1909 & Rafael Altamira & $\begin{array}{l}\text { Sanz y Escartín, Piernas y } \\
\text { Hurtado, Sánchez de Toca, García } \\
\text { de San Miguel }\end{array}$ \\
\hline $\begin{array}{l}2^{\text {nd }} \text { December } \\
1913\end{array}$ & Adolfo González Posada & Azcárate, Sánchez de Toca, Ureña \\
\hline $8^{\text {th }}$ March 1916 & Adolfo Buylla & $\begin{array}{l}\text { Azcárate, Sánchez de Toca, } \\
\text { Altamira }\end{array}$ \\
\hline 16 $6^{\text {th }}$ April 1918 & Julio Puyol y Alonso & $\begin{array}{l}\text { Posada, Buylla, Ureña, Bonilla, } \\
\text { López Muñoz, Salvador y } \\
\text { Rodrigáñez }\end{array}$ \\
\hline
\end{tabular}

The speeches of Azcárate and de Santamaría de Paredes respectively devoted to "the concept of society" and "the social organism", constituted crucial steps towards the inclusion of sociology within the moral and political sciences ${ }^{116}$. These speeches present "society", organized as an organic body, as the subject of sociology. Based on analogy, the organicist theories of social issues equated society with an individual biological organism ${ }^{117}$. Society is a living thing because it is made up of living components (individuals) and continues existing even if individuals disappear. Moreover, it is subject to the same natural laws as other living creatures, particularly the law of evolution presented by Spencer as a transition from simple to more complex forms of organization via a functional specialization. Azcárate and Santamaría de Paredes considered this social

116 Azcárate, de (1891), Santamaría de Paredes (1896).

117 Social organicism became popular in Spain in the 1880s thanks to the translation of Spencer's sociological works and Albert Schäffle's Quintessenz des Socialismus (1874), translated by Adolfo Buylla and Adolfo Posada in 1885. Nuñez Ruiz (1975 : 252), Ureña (2009 : 133). 
theory as the condition for the emergence of scientific sociology. Unlike the encyclopedic tradition, which divided the sciences according to the differences derived from the faculties of the spirit, the nineteenth century classified them according to their place in the natural world ${ }^{118}$. In these conditions, the recognition of sociology implied a new (natural) reality to be studied, and allowing its inclusion in the classification of sciences where it would not replace any of the existing moral and political sciences. Social organicism helped in the conceptualizing of this new subject (i.e. society as an organic entity) through a naturalistic lexicon ${ }^{119}$. But the admission of positivist sociology within the moral and political sciences required that it remain nonetheless a "moral" science. That is why the aforementioned academicians endeavored to propose a spiritualist interpretation of organicist theories, close to the concept of "people" in the philosophy of history and in the contemporary German humanities: that is, a collective being endowed with a spirit ("Volkgeist") ${ }^{120}$. This interpretation can be detected in the terms chosen to characterize society, described as a "moral" and "rational" organism, a "natural" and "supernatural" being, a "subject" of social life ${ }^{121}$. This personalization of society allowed academicians to maintain the separation between society and the natural world because the reference organism through which society was considered was still man as a dual (spiritual) being. By choosing to adhere to Spencerian evolutionism, the academicians who defended sociology also expressed a preference for the less literal variant of the organicist metaphor, according to which evolutionism was compatible with Catholic dogma and the Augustinian theory of "potential creation"122. They also denounced the metaphysical "mistakes" of naturalism which replaced with ontological propositions (i.e. the definition of society as a living being) the theological definition of society its method had contributed to destroy $^{123}$. These academicians were the ones who confronted the last opponents of the admission of sociology within the Academy, particularly the metaphysics professor Juan Manuel Ortí y Lara ${ }^{124}$, a Thomist, an adversary of evolutionism, defender of "traditional" political sciences and an unsuccessful candidate for nomination to the chair of sociology in $1898^{125}$.

118 Blanckaert (2006:117-148).

119 Blanckaert (2004: 19).

120 Diaz (1973 : 231-337), Ortiz (1999).

121 Trautman Waller (2004 : 14-15).

122 Sanz y Escartín (1898), (1905).

123 Santamaría de Paredes (1896: 72).

124 In two academic discussions: Método procedente en el estudio de los hechos sociales, 1901 and Discusíón acerca de la persona y doctrinas filosóficas de Herbert Spencer (1904).

Nuñez Encabo (1999 : 57-69).

125 Nuñez Encabo (1999 : 57-69). 


\subsection{Social issues and criticism of the liberal sciences: civil law and political economy}

Furthermore, it is important to take into account the political context during which sociology was introduced within the Academy. The 1890 s were a period of crisis characterized by the rise of the labor movement. The social question was placed on the political agenda and the majority of Spanish parties also supported State intervention in the economy ${ }^{126}$. During this period, the Academy broke with the liberal economic principles as a result of intense debates (18891894) on social insurance and the possibility of introducing into Spain the Bismarckian welfare state model ${ }^{127}$. Academicians who opposed this orientation (Figuerola, Fernando Cos Gayón, Raimundo Fernández Villaverde, Melchor Salvá) drew their arguments from liberal economics and law. Their rejection of the notion of "social class" in the name of civil liberty, their individualistic approach to labor disputes and their interpretation of workers' collective rights as privileges or a new form of tax undermined, from their opponents' point of view, both the understanding of social problems and the possibility of solving them ${ }^{128}$. This is why the interventionist academicians drew their inspiration from the critical currents of classical political economy.

The academicians who introduced these heterodox economic theories within the Academy were also those who contributed to the recognition of sociology in the institution ${ }^{129}$. Azcárate and Santamaría de Paredes, as members of the Comisión de Reforma Sociales (Social Reform Commission), were committed to setting out labor law ${ }^{130}$. In 1903, they became the heads of the Instituto de Reforma Social (Social Reform Institute) which then replaced the Commission. Between 1903 and 1906, several academicians such as Sanz y Escartín, Piernas y Hurtado, Sales y Ferré, Fernandez Villaverde, Sánchez de Toca, Posada, Buylla and Bonilla became members of this Institute ${ }^{131}$. Azcárate and Santamaría de Paredes defended a critical economic liberalism against the classical school at the Academy. They presented the theories of the social economy (Charles Gide) through the issue of taxation, and socialist

126 Comín Comín (1999), Castillo (2001).

127 Montero (1980: 121-165), Malo Guillén (1999).

128 Bases de una legislación más completa que la actual, para indemnizar a los trabajadores ó sus familias de las desgracias ocasionadas por la incuría de los jefes y propietarios de establecimientos industriales (1889), Significación y consecuencias probables de los recientes rescriptos del Emperador de Alemania sobre la legislación nacional e internacional del trabajo, y el estado de la opinión en las diferentes escuelas y Gobiernos respecto de dicho punto (1890).

129 On the link between social sciences and the "social question", see Wittrock, Wagner, Wollmann, (1991: 32-38), Nuñez Ruiz (1979).

130 Between 1893 and 1901, Azcárate and Santamaría de Paredes took up the responsibility of examining new journals which reduced the relative share of economic journals (le Journal des économistes, L'Economiste Français) in the subscriptions of the Academy. Two Catholic journals devoted to social studies were among them (Rivista Internazionale di Scienze Sociale y discipline auxiliare, La Sociologie catholique) and Benoît Malon's La Revue socialiste

131 Calle Velasco, de la (1989), Palacio Morena (1988). 
theories by discussing the organization of work (Karl Marx, Albert Schäffle) or agrarian collectivism (Emile de Laveleye) ${ }^{132}$. Regarding social issues, Sanz y Escartín used the proposals of the Christian social economy ${ }^{133}$, updated in 1891 by the pontifical encyclical De conditione opificum, as well as those of German economists who were supporters of the interventionist policies launched by Chancellor Bismarck in the $1880 \mathrm{~s}^{134}$. The socializing economic theories changed the interpretation of social issues perceived from then on as the result of the liberal transformation of the organization of labor. These theories also modified the measures under consideration to solve the crisis because they valued institutions which were usually denigrated by the liberal doctrine, such as corporations, collective property and state labour regulation. This socialization of economic activities was described according to the patterns of the organicist sociology and the German organic theory of State which had a strong influence on the Spanish public law ${ }^{135}$. For example, the creation of public monopolies at the municipal level (e.g. water supply and bread distribution) was based on a description of the town as an organic extension of the family and its community practices ${ }^{136}$. This academic critique of economic liberalism is well known ${ }^{137}$. Here it was accompanied by a reflection on the defects of the Spanish political system such as caciquism, electoral corruption and a questioning of liberal public law. In a series of debates held between 1890 and 1907, the Academy in fact questioned the uniformity of the local administrative regime and electoral law, proposing reforms which contradicted them: equality before the law, administrative homogeneity, the representative system and universal suffrage ${ }^{138}$. These "regenerationist" propositions drew inspiration on the one hand from the liberal critique of centralization in the name of "self-government", and, on the other, from the counter-revolutionary denunciation of the destruction of local institutions described as shredded living bodies ${ }^{139}$. From 1894, the Academy adopted these new theories due to the gradual disappearance of a generation of economists (e.g. Madrazo, Colmeiro and Figuerola) who had a liberal stance on both economic and political issues. They had helped to bring into the Academy Krausists who were born in the 1840s and the 1850s and who had initiated a critique of the social implications of economic liberalism in the

${ }^{132}$ Santamaría de Paredes (1893), El Impuesto progresivo sobre rentas y utilidades (1896).

133 Montero (1999).

134 Schiera (1991: 93- 120), Grimmer-Solem (2006 : 89-145).

135 Argyardis Kervégan (2006), Capellán de Miguel (2011 : 176-188), Stolleis (2014: 153169, 593).

136 Ventajas o inconvenientes de la ampliación de los servicios sociales a cargo de los Municipios (1901).

137 Malo Guillén (1999 : 495-524).

138 ¿ Hasta que punto es compatible en España el regionalismo con la unidad necesaria del Estado ? (1899), De la unidad del régimen municipal (1890), Ventajas o inconvenientes de convertir el Derecho de sufragio en una función pública obligatoria (1893), Representación política de las corporaciones, asociaciones y fundaciones (1900).

139 Pro Ruiz (1998 : 191-212). 
$1870 \mathrm{~s}^{140}$. The evolution of the Academy's economic and political doctrine was thus the result of a convenient alliance between the conservatives (Conde de Torreánaz, Sánchez de Toca, Sanz y Escartín) who were traditionally hostile to liberalism, and reformist and republican liberals (Linares Rivas, Azcárate, Aguilar y Correa, Santamaría de Paredes) who proposed a theoretical revision of economic liberalism ${ }^{141}$. This alliance was fragile and frayed during some debates (e.g. reestablishment of professional corporations and compulsory voting). But this alliance expressed itself through a common organicist approach, which was a mix of different traditions such as neo-Thomism, sociological theory and conservative historicism ${ }^{142}$. This organicist approach produced a joint and functionalist view of society that attacked legal individualism during the 1890s, when the implementation of the liberal program (freedom of expression and association, universal suffrage) was being finalized. In a scientific institution, the attacking of liberal doctrines ends up affecting on an epistemological level the disciplines which conceived them, such as civil law and political economy ${ }^{143}$. Hence, during a debate on "state socialism" in 1894, the interventionists challenged the scientific status of political economy, thus forcing its practitioners to defend their discipline collectively. This calling into question of economics relied heavily on the works of the German historical economics school. According to Adolph Wagner, one of its theorists, every action obeys laws and customs (that is to say both rules and social habits), whereas economics gave only a restricted description of individual acts without connecting them to their social and historical context and these acts seemed only to be defined by passions conceived as moral invariants ("interests"). More importantly, the German theorists and their followers in the Academy considered that political economy was unable to solve the social issues of the day and to curb the progress of socialism which had become a political threat since the adoption of universal suffrage in 1890.

\subsection{The legacy of the German historical school of law and the spiritualist organicism}

This ideological and epistemological critique of moral and political sciences brought about a scientific reclassification in favor of disciplines (i.e. sociology and history of law) which supported state social intervention or the rebirth of regulatory bodies. It also imposed a renewal in the moral and political sciences, which were gradually qualified as "social sciences"144. Thus, in order to remain

140 Suárez Cortina, (2000 : 50-65), Malo Guillén (2005 : 26-27).

141 Some of the conservatives who had a liberal stance on economic issues (Fernández Villaverde and Cos Gayón) were against liberal economists such as Figuerola and Colmeiro.

142 Gil Cremades (1969), Nisbet (1944).

143 On the critique of political economy as a crucial step in the institutionalization process of sociology, see Goldman (1983 : 591-98), Karsenti (2006 : 36-39), Steiner (2008).

144 Altamira (1900). 
(social) sciences, law and economics had from then on to study collective entities (institutions) or social facts as physical or psychological units from which a collective psychology or sociology could be produced, in accordance with moral organicism theories. The social sciences were defined as empirical sciences, which find their material in history. This epistemological program was implemented at the Academy by Gumersindo de Azcárate y Joaquín Costa, with the organization of a contest on common law and popular economics (1898$1918)^{145}$. This contest was designed to encourage monographic enquiries into customary practices described as "living laws", which had their roots in popular culture and archaic social practices. It also aimed to rehabilitate the custom as a democratic and local source of law in the context of the regenerationist criticism of the parliament and of the unification of the Spanish civil laws in a Code (1889) ${ }^{146}$. The winning submissions showed the evolutionary and socialist inflexion of the history of law during that period. Following the works of Johannes Bachofen, they bucked the tide of the history of liberal law by postulating the matriarchal and communist nature of primitive societies ${ }^{147}$. At the turn of the century, these theories became the official content of academic sociology. Their teaching was based on the treatise of Sales y Ferré, who proposed a universal history of civil and political institutions since prehistory in which the evolutionary scheme replaced a chronological account of facts ${ }^{148}$. Some Academicians have described the entry of sociology and its naturalistic theories and lexicon as an epistemological break with the past. However, this must be put into perspective in many respects. Firstly, it must be pointed out that this change was less of a real encounter between the natural sciences and the moral and political sciences, than that of a dynamic specific to the moral and political sciences. Since the establishment of the Academy, these sciences had been largely represented by lawyers, who were the first Spanish sociologists. This can partly be explained by the fact that law prepared them to study collective subjects such as "the institutions"149, which were described in the late nineteenth century public law treatises as "living organizations" (e.g. corporations) or "natural" ones (e.g. family, nation) $)^{150}$. Moreover, legal categories played a cognitive role which was well-known in the acceptance of the organicist theories. This was especially true of the concept of "persona moral" (juridical person), which refers to a group of natural persons whose subjective individual rights are recognized. Frequently used by the Krausists to describe society, this legal fiction showed the capacity of law to individualize collective realities in an abstract way ${ }^{151}$.

The metaphors of the political body and the scholastic conceptions of

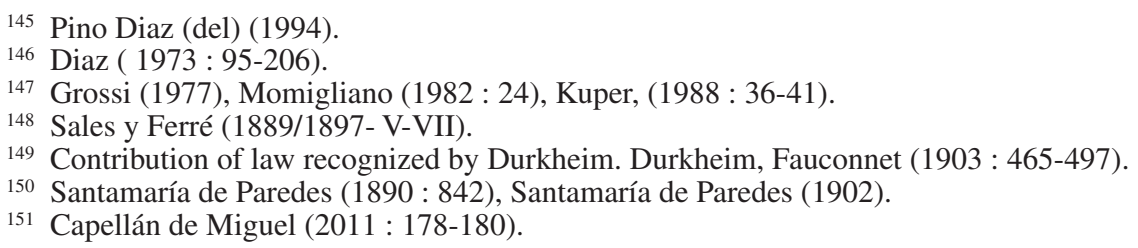


the birth of political societies based on the biological substrata of the family were familiar to the academicians ${ }^{152}$. What was new in the second half of the nineteenth century was that this evolutionary organicism became a scientific program. Yet, this process stemmed in large part from the changes in the history of law and its political uses. From then on, this was indeed influenced by Spencer's theory and mobilized to regenerate collective forms of social and economic organizations, which could be traced back to "primitive" law, especially German. The Krausists contributed to the development of this new organicist history of law whose filiations with the German Naturphilosophie (Schelling), to which Krausism was historically linked, has been shown by historians ${ }^{153}$. The spiritualist orientation of academic social organicism indicated another limit of the range of epistemological change in the 1890s. Among the personalities who were considered as "sociologists" between 1890 and 1910, those who entered the Academy were either lawyers (e.g. Santamaría de Paredes, Azcárate, Adolfo González Posada), or economists (e.g. José Manuel Piernas y Hurtado, Adolfo Álvarez Buylla, Julio Puyol y Alonso). Part of the representatives of Spanish sociology remained outside the institution, such as psycho-sociology (e.g. Urbano González Serrano) and criminal anthropology (e.g. Rafael Salillas, Pedro Dorado Montero, Constancio Bernaldo de Quirós). Conversely, in 1919, the Academy elected Severino Aznar, who had succeeded Sales y Ferré as the chair of sociology at the university. Aznar came from the field of Catholic social action and as such was not a representative of "scientific" sociology $y^{154}$. This succession reflects the continued competition between Krausists and Neo-Thomists for the control and definition of the new science. The particularities of academic sociology can partly be explained through the importance of the notion of "individual consciousness" in the moral and political sciences. It can be seen in the success of collective psychology at the Academy and the consequent rejection of experimental psychology. Neither the individuation of collective beings nor the attribution of a "mind" to human communities posed a problem for academicians. Instead they provided a framework to think in terms of regional and national identity (psychology of peoples), as well as collective worker action (crowd psychology) ${ }^{155}$. What they refused was the physiological approach to psychic phenomena, as seen in 1903, when the application of the Bishop of Madrid was preferred over that

152 Schlanger (1971: 191-225).

153 Diaz (1973: 187-213).

$154 \mathrm{PhD}$ in Philosophy, in 1904 Aznar joined the social Catholic movement under the influence of Salvador y Barrera, the Bishop of Tarragona, and he contributed to the foundation of social catholic publications with the editorial collection "Ciencia y acción" in which he published in 1915 an anthology of Le Play's texts. His application to the Academy was supported by social catholics: Alvaro López Nuñez, Manuel Burgos y Mazos and Miguel Asín Palacios (Libro de actas, 28 octobre 1919). Iglesias de Ussel (2001: 101-127). On the project of a Catholic sociology, see Serry (2004 : 28- 40).

155 Academic discussion ¿ Como se explica la rapidez con que el Japón se ha asimilado la civilización européa ? (1908-9), El delito colectivo (1913). Ortiz (1999). 
of psycho-sociologist Urbano González Serrano by the Academy ${ }^{156}$. This was also reflected in the criticisms addressed by Sanz y Escartín with regards to the investiture speech of Sales y Ferré. The speech was devoted to the " positive foundations " of morals, that is, to a psychological and historical approach to the emergence of moral obligation in children and "primitive" peoples ${ }^{157}$. Their evolutionism applied only to society and they refused the parallelism established by Spencer between the stages of social and mental development, which made man an "unfinished" creature ${ }^{158}$. In the 1920 s, in response to the extension of psychology towards the natural sciences ${ }^{159}$, the academicians elected neoThomist professors of philosophy who held psychology $\mathrm{PhDs}$, in order to represent this discipline in the institution ${ }^{160}$. Although the moral and political sciences became social sciences, they retained large parts of their spiritualist and individualist orientation.

\section{CONCLUSION}

The emergence of social sciences which used the vocabulary and methods of the science of nature was interpreted as a major epistemological development in the history of sciences. In order to understand this we have chosen to study an institution devoted to the moral and political sciences and established before social sciences were constituted as disciplines. The Academy as an authority on the legitimization of knowledge, contributed, at the end of the nineteenth century, to the recognition of the scientific status of sociology and the definition of a common program for social sciences. In a way, these were derived from a transformation of the moral and political sciences. The study of the Academy over a long period provides the opportunity to follow these steps and interpret their causes. In 1857, the institution of the moral and political sciences in Spain was based on the French model of the " second" foundation of these sciences, with the establishment of the French Academy in 1835. These sciences were set up by a liberal but conservative government which admitted the possibility of a science of man and of government but in the controlled framework of the Royal Academy, placed under the authority of the executive power. In this context of restricted liberalism, the Academy was responsible for defining the official political doctrine of the regime. The sciences represented at the Academy were influenced by Christian anthropology and perceived man as a

156 Jiménez García (1986 :123-127).

157 Sales y Ferré (1907), Eduardo Sanz y Escartín's response.

158 Mena y Zorrilla (1892).

159 The first chair of experimental psychology was created in 1902 within the Faculty of Science. Lafuente Niño (1980 : 138-147).

160 Juan Zaragüeta Bengoechea and Arnáiz Calvo, disciples of Cardinal Mercier (founder of the Higher Institute of Philosophy of Louvain) became honorary members of the Academy in 1918. The first experimental psychology specialist to be elected by the Academy in 1932 was Julian Besteiro, who was also the first socialist to join the institution. Saiz, Saiz (1996 : 243-252). 
being endowed with an immaterial spirit. Through this spiritualist conception of man we can understand why the study of man was divided between the natural sciences and the moral and political sciences: the former dealt with the corporal dimension of man, the latter distinguished man through his actions and social relations as a moral being. It also helps us to understand the absence of studies specifically devoted to human nature and the origin of man. These issues were indeed subject to prior definition, the dogmatic dimension of which was heightened by the presence of theologians in the Academy. The moral and political sciences rather studied man's actions and the rules that governed him, be they historical laws or natural law, and focused less on man himself. Thus the reducing of the moral and political sciences to the sciences of government can be explained by the Academy's political objectives but also by their practitioners' spiritualism and adherence to the theories of natural law. The liberal revolution of 1868 and the spread in Spain of naturalistic theories on the origin of man and the establishment of human societies greatly undermined the metaphysical foundations of the moral and political sciences. On an ideological level, the moral and political sciences also suffered from the critique of liberalism; liberalism had to face social issues from the 1880s onwards, both the problem of the economic crisis and political democratization. The Academy responded by increasing its participation in public debates and became a center for the refutation of socialism and naturalistic theories. However, in the 1880s, it finally included new sciences in its scientific scope of study (i.e. sociology, collective psychology), a new subject (society) and new theories (i.e. organicism, evolutionism) which modified the epistemology and the ideology of the moral and political sciences. They came to be defined as "social sciences", that is to say sciences dealing with social facts and whose objective was to solve social issues through an empirical method of investigation. The texts written from these investigations are studied today in separate historiographical fields, according to various disciplinary forms of reasoning. Social surveys are indeed part and parcel of the history of sociology ${ }^{161}$ and monographs on common law are studied as the first anthropological works ${ }^{162}$. The study of an institution such as the Academy, which was the fruit of both a scientific and political logic, enables us to understand the homogeneity of its intellectual production. The Academy is indeed a meeting point between the "social science" of Le Play and evolutionary "sociology". It is the theatre of a significant meeting between Krausist lawyers, pioneers in the teaching of sociology, representatives of Christian social economics and the Spencerians. The existence of a consensus on the solutions to be brought to bear on social issues made this synthesis feasible. This interventionist consensus did not exclude some divergences of opinion, considering that the critique of liberalism was different in form and intensity depending on whether it came from the conservatives or from the "neo-liberals".

161 Martín López (2003 : 70-78) ; Zarco (1999: 129-156).

162 Assier-Andrieu (2001), Pino Díaz, del (1994). With the exception of Duque, Gómez Benito, (2006). 
But these divergences reflect the structural fragility of the liberal economic theory among the Spanish elites, as can be observed in how consistent the criticisms of political economy in the Academy had been since its foundation. Although in the 1860 s political economy was criticized for its "immorality", it was also considered as an instrument to refute scientific socialism. The advent of a social or even socialist doctrine in German economics managed to bring an end to this weakened discipline to the benefit of another "nomothetic" science - sociology. The other reason why "sociology" and "social science" converged came from a fairly broad acceptance of the organicist and evolutionary theories, reinterpreted in the familiar and spiritualist terms of the Historical School of law. The existence of an anti-liberal, organicist and empirical tradition in the moral and political sciences tends to put into perspective the change caused by the advent of the social sciences into the Academy and the role the natural sciences played in their development. The refusal of any experimental approach regarding psychic phenomena and the upholding of an alternative catholic sociology strictly defined as a science of social action illustrate the limits of this change.

\section{SOURCES}

\section{HAND-WRITTEN SOURCES}

Academia de la Historia. Archivo Cabanilles, legajos 41 y 52, Academias (Historia y ciencias morales y políticas), "Opusculos publicados por la ASMP". The hand-written note allows us to set the date to 1848 .

Libro de actas de la Real Academia de ciencias morales y políticas.

\section{Printed sources}

ALTAMIRA, R., (1900) : L'enseignement des sciences sociales en Espagne ", Congrès International de l'enseignement des sciences sociales, 30 juillet-3 août 1900, Paris, Alcan.

CARDENAS (de), F. (1870) : "El matrimonio en sus relaciones Históricas con el Estado y con la Iglesia", Revista de España, Madrid, Tercer año, Tomo XIV, pp. 345-389.

COLMEIRO, M. (1865) : Elementos del derecho político y administrativo de España, (2nda ed.), Madrid, Imp. De Martínez García.

D’ALEMBERT (1894) : Discours préliminaire de l'Encyclopédie, Paris, publié intégralement d'après l'édition de 1763, par F. Picavet, Armand Colin Éditeurs.

DIETRICH (de), A. (1898) : Préface de SANZ Y ESCARTÍN, E. L’individu et la réforme sociale, Paris, F. Alcan. 
GINER DE LOS RÍOS, F. (1899) : Teoría de la persona social, estudios y fragmentos, Madrid, Librería general de Victoriano Suárez.

PUFENDORF, S. (1672), De jure naturae et gentium, libri octo, Londoni Scanorum : sumptibus A. Junghans.

SALES Y FERRÉ, M. (1889-1897) : Tratado sociología. Evolución social y política, Madrid, Librería de Victoriano Suárez.

SANTAMARÍA DE PAREDES, V. (1890) : Curso de derecho político según la filosofía política moderna, (4 ed ), Madrid. Tip. Ricardo Fe.

SANTAMARÍA DE PAREDES, El concepto de sociedad, Discurso leido en la Universidad central, inauguración curso 1901-1902.

SANZ Y ESCARTÍN, E. (1898) L'individu et la réforme sociale, Paris, F. Alcan.

SANZ Y ESCARTÍN, E. (1890), La cuestión económica, Madrid.

SANZ Y ESCARTÍN, E. (1893), El Estado y la réforma social, Madrid.

SCHÄFFLE, A. (1885) : La Quinta esencia del socialismo, traducción y notas de Adolfo Buylla and Adolfo Posada, Madrid, M. G. Hernández.

\section{Discourses : «Discursos de recepción y de contestación leidos ante la Real Academia de ciencias morales y políticas ».}

AZCÁRATE, de (1891) : Concepto de sociología.

CAMINERO Y MUÑOZ, F. J, (1881) : La filosofía disidente, en lo que tiene de tal, no puede darnos la verdad; y en sus aplicaciones a las Ciencias morales y políticas no puede darnos el bien,

CÁNOVAS DEL CASTILLO, A. (1881) : Las últimas hipótesis de las ciencias naturales no dán más firmes fundamentos a la sociología que las creencias, aún miradas támbien como hipótesis, en que los estudios sociológicos han solido buscar sus cimientos hasta ahora.

GONZÁLEZ, C. (1883) : La causa principal, originaria, ya que no la única, del malestar que esteriliza y detiene la marcha de la sociedad por los caminos del bien, es esa gran negación oculta y encarnada en el principio racionalista : la negación de Dios, la cual es principio generador de mal en todas sus formas.

LASALA Y COLLADO, F. Duque de Mandas, ¿Cuáles son la ley histórica y el principio filosófico à que pueden obedecer las revoluciones? (1882).

MADRAZO, S. D. (1864) : Relaciones de la Economía política con la Moral y el Derecho.

MENA Y ZORILLA (1892) : Examen crítico de la moral naturalista.

PASTOR, L.M. (1863) : Reflexiones sobre la importancia que va adquiriendo el estudio de la Economía política, Contestación de Antonio Benavides.

PERIER Y GALLEGO, C.M. (1881) : La armonía en la civilización es el gran problema que este siglo crítico, gigante en lo material, pero incierto en lo filosófico y flaco en lo moral, lega al siglo siguiente.

PIDAL Y MON, A. (1887) : De la metafísica contra el naturalismo. 
PIDAL Y MON (Marqués de Pidal), L. (1887) : Del método de la observación en la ciencia social; Le Play y su escuela.

SALES y FERRÉ, M. (1907) : Nuevos fundamentos de la moral, Contestación de Eduardo Sánz y Escartín.

SANTAMARÍA DE PAREDES, V. (1893) : El movimiento obrero contemporáneo : su exposición histórica y doctrinal, critica de las ideas económicas en que se apoya ; examen de las soluciones que son compatibles con la misión del Estado.

\section{Reports : «Memorias de la Real Academia de ciencias morales y politicas »}

ALONSO MARTÍNEZ, M. (1875) : Estudios sobre filosofía del Derecho, Nociones fundamentales del derecho; Teoría de los derechos individuales; la familia; historia de la familia; Estudio sobre el derecho de propiedad.

ALONSO MARTÍNEZ, M. (1876) : Movimiento de las ideas religiosas en Europa. Exposición y crítica del sistema krausista.

ALONSO MARTÍNEZ, M., (1883) : Influjo del positivismo en las ciencias morales y políticas.

AZCÁRATE (de), G. (1891) : Concepto de sociología.

FIGUEROLA, L. (1861) : Filosofía del trabajo.

GONZÁLEZ Y DÍAZ TUÑON, C. (1883) : La causa principal, originaria, ya que no la única, del malestar que esteriliza y detiene la marcha de la sociedad por los caminos del bien, es esa gran negación oculta y encarnada en el principio racionalista : la negación de Dios, la cual es principio generador de mal en todas sus formas.

LASALA Y COLLADO, Duque de Mandas, F. (1882) : ¿Cuáles son la ley histórica y el principio filosófico à que pueden obedecer las revoluciones?

MADRAZO, S.D., (1864) : Relaciones de la Economía política con la Moral y el Derecho.

SANTAMARÍA DE PAREDES, V. (1893) : El movimiento obrero contemporáneo : su exposición histórica y doctrinal, critica de las ideas económicas en que se apoya ; examen de las soluciones que son compatibles con la misión del Estado.

SANTAMARÍA DE PAREDES, V. (1896) : Concepto de Organismo social

SANZ Y ESCARTÍN, E. (1890) : La cuestión económica, Madrid, Imp. de Antonio Pérez Dubrull.

SANZ Y ESCARTÍN, E. (1893) : El Estado y la réforma social, Madrid, Imp. de Soc. Edit. de S. Francisco de Sales.

SANZ Y ESCARTÍN, E. (1898), La doctrina evolucionista,

SANZ Y ESCARTÍN, E. (1905) : Evolucionismo cristiano.

RODRÍGUEZ VAAMONDE, F. (1874) Estudio sobre la propiedad enfitéutica y las leyes de 20 de agosto y 16 de setiembre relativas a la redención de foros y otras cargas territoriales. 
TEJADA (de), S. (1862), La libertad, la autoridad, la Iglesia católica.(primera parte).

TEJADA (de), S. (1863) : Juicio crítico sibre los principios de 1789 en Francia.

TEJADA (de), S. (1865) El Imperio Austriaco y su nuevo gobierno constitucional.

\section{- Statements : « Informes »}

Informe sobre la influencia del teatro en las costumbres públicas (1860).

Informe sobre la reforma de las leyes de inquilinato y los medios de contener el aumento desproporcionadop de los alquileres de edificios (1863).

\section{- Academic Discussions}

De la conveniencia o inconveniencia de la libertad de comercio atendidas las actuales condiciones de España (1859-1860).

Bases de una legislación más completa que la actual, para indemnizar a los trabajadores ó sus familias de las desgracias ocasionadas por la incuría de los jefes y propietarios de establecimientos industriales (1889).

Significación y consecuencias probables de los recientes rescriptos del Emperador de Alemania sobre la legislación nacional e internacional del trabajo, y el estado de la opinión en las diferentes escuelas y Gobiernos respecto de dicho punto (1890).

De la unidad del régimen municipal (1890).

Ventajas o inconvenientes de convertir el Derecho de sufragio en una función pública obligatoria" (1893).

El Impuesto progresivo sobre rentas y utilidades (1896).

¿. Hasta que punto es compatible en España el regionalismo con la unidad necesaria del Estado ? (1899).

"Representación política de las corporaciones, asociaciones y fundaciones" (1900).

Ventajas o inconvenientes de la ampliación de los servicios sociales a cargo de los Municipios (1901).

Metodo procedente en el estudio de los hechos sociales (1901)

Discusíón acerca de la persona y doctrinas filosóficas de Herbert Spencer (1904).

¿ Como se explica la rapidez con que el Japón se ha asimilado la civilización européa ? (1908-9).

El delito colectivo (1913).

\section{- Obituary Notice}

SANZ Y ESCARTÍN, E. (1912) : Necrología del Excmo Sr. D. José Piernas y Hurtado, Necrologías de los señores académicos de número fallecidos desde $1 .^{\circ}$ de julio de 1885 . 


\section{BIBLIOGRAFÍA}

AGUILAR PIÑAL, F. (1985) : Las Academias, La época de los primeros Borbones, Vol. 2 : La cultura española entre el Barroco y la Ilustración (circa 1680-1759), Madrid, Espasa Calpe, pp. 149-193.

ANTÓN MELLÓN, J. (1989) Las ideas sociales en la Real Academia de Ciencias Morales y Políticas (1875-1902), Barcelona, Publicacions de la Universitat Autónoma de Barcelona.

ARGYRIADIS-KERVEGAN, C. (2006/1) : "L'administration locale entre nature et état dans la pensée allemande du XIX ${ }^{\mathrm{e}}$ siècle", Revue française d'histoire des idées politiques, $\mathrm{n}^{\circ} 23, \mathrm{pp} .83-128$.

ASSIER-ANDRIEU, L. (2001) : "Penser le temps culturel du droit. Le destin anthropologique du concept de coutume", L'Homme, 160, 2001, "Droit, coutume, mémoire ", pp. 67-90.

BAENA DEL ALCÁZAR, M. (1997) "La generación primitiva de administrativistas y la moderna ciencia de la administración", in Gil Cremades, J.J., Seoane Vacas, C., Vicente y Guerrero, G., Nagore Laín, F. (coord.), La configuración juridico política del estado liberal en España : actas del Congreso en conmemoración del segundo centenario del nacimiento de Alejandro Oliván (1796-1996), Huesca, 12-13 de diciembre de 1996, Universidad de Zaragoza, Escuela Universitaria de Estudios Empresariales de Huesca, 1997. p. 145-160.

BAKER, K. (1975) : Condorcet : from natural philosophy to social mathematics, Chicago ; London, University of Chicago press.

BARÓ PAZOS, J. (1992) : La codificación del derecho civil en España, 1808-1889, Santander, Publicaciones de la Universidad de Cantabría.

BAUDEAU, N. (1767) : Ephémérides du citoyen, ou Bibliothèque raisonnée des Sciences morales et politiques, 1767, T. I., Paris, N.A. Delalain.

BECQUEMONT, D., MUCHIELLI, L. (1998) : Le cas Spencer. Religion, science et politique, Paris, PUF.

BECQUEMONT, D. (2003/1) : Positivisme et utilitarisme : regards croisés, Comte, Spencer, Huxley, Revue d'histoire des sciences humaines, n`8, pp. 57-72.

BELTRÁN VILLALVA, M. (2004) : "Spencer organicista”, Reis, Revista española de investigaciones sociológicas, $\mathrm{n}^{\circ} 107,2004$, pp. 227-230.

BLANCKAERT, C (1999) : L'histoire générale des sciences de l'homme. Principes et périodisation, In Blanckaert, C., Blondiaux, L., Loty, L., Renneville, M. Richard, N. L'histoire des sciences de l'homme. Trajectoires, enjeux, questions vives, Paris, L'Harmattan, pp. 23- 60.

BLANCKAERT, C (2002) : “1800. Le moment "naturaliste” des sciences de l'homme", Revue d'Histoire des Sciences Humaines, 3, pp. 117-160.

BLANCKAERT, C. (2004) : La nature de la société. Organicisme et sciences sociales au XIX ${ }^{\mathrm{e}}$ siècle, Paris, L'Harmattan.

BLANCKAERT, C. (2006) : "La discipline en perspective, le système des sciences à l'heure du spécialisme (XIX ${ }^{\mathrm{e}}-\mathrm{XX}^{\mathrm{e}}$ siècle)", en Boutier, J., Passeron, J.C., Revel, J. (eds.), Qu'est-ce qu'une discipline ? Paris, Editions de l'EHESS, pp. 117-148. 
BOURDEAU, M. (2003/1) : La réception du positivisme (1843-1928), Revue d'histoire des sciences humaines, $n^{\circ} 8$, pp. 3-8.

BURDIEL I., (2010) : Isabel II : una biografía (1830-1904), Madrid, Taurus ediciones.

CACHO VIU, V. (1962), La institución libre de enseñanza. I. Orígenes y etapa universitaria (1860-1881), Madrid, Rialp.

CALLE VELASCO (DE LA), M.D. (1989) : La Comisión de reformas sociales (18831903). Politica social y conflicto de intereses en la España de la Restauración, Madrid, Centro de publicaciones, Ministerio de Trabajo y Seguridad Social.

CAPELLAN DE MIGUEL, G. (1998) : “La renovación de la cultura a través del pensamiento alemán : Krause y el Krausismo", BROCAR, 22, pp. 137-153.

CAPELLAN DE MIGUEL, G. (1999/1) : "Entre"españolismo" y"extranjerismo" : el origen de la polémica sobre la ciencia española, in Xavier Agenjo Bullón, Gonzalo Capellán de Miguel, Hacía un nuevo inventario de la ciencia española : IV Jornadas de Hispanismo Filosófico, Santander, 1999, pp. 159-172.

CAPELLAN DE MIGUEL, G. (1999/2) : "Krausismo y neotomismo en la cultura de fin de siglo", en Súarez Cortina, M. (ed.) La cultura española en la Restauración, I Encuentro de Historia de la Restauración, Santander, Sociedad Menéndez y Pelayo.

CAPELlÁN DE MiGUEL, G. (2005) : «Orígenes de la Sociología en España : Azcárate y la Escuela de Estudios Superiores del Ateneo, in : Agenjo Bullón, X., Ordén Jiménez, R.V., Jiménez García, A (dir.), Nuevos estudios sobre historia del pensamiento español : Actas de las V Jornadas de Hispanismo filosófico (Santander 2001), Santander, Fundación Larremendi, p. 253-272.

CAPELLAN DE MIGUEL, G. (2006) : La España armónica. El proyecto del krausismo español para una sociedad en conflicto, Madrid, Biblioteca Nueva.

CAPELLAN DE MIGUEL, G. (2011), De la filosofía a la ciencia política : una aportación fundamental-y olvidada- del krauso-institucionismo español, in Cortina Suárez, M., Libertad, armonía y tolerancia : la cultura institucionista en la España contemporánea, Madrid, Tecnos, pp. 152-212.

CARPINTERO CAPELL, H, LAFUENTE NIÑO, E. (1996) : Luis Simarro y los orígenes de la psicología científica en España, Madrid, UNED.

CASTILlO ALONSO, S. (2001) : Marxismo y socialismo en el siglo XIX español, in Ortiz Heras, M., Ruiz González, D., Sánchez Sánchez, I. Movimientos sociales y Estado en la España contemporánea, Cuenca, Ediciones de la Universidad de Castilla la Mancha, pp. 81-126.

CASTRO ALFÍN, D. (1998) : Los males de la imprenta : política y libertad de prensa en una sociedad dual, Madrid, siglo XXI de España.

CEREZO GALÁN, P. (2002) : "El espacio ideológico de la Real Academia de Ciencias Morales y Políticas", en Herrero y Rodríguez de Miñon, M. y Scholz, J. M. (coord.), Las ciencias sociales y la modernización. La función de las Academias, Madrid, Academia de Ciencias Morales y Políticas, pp. 73-172.

CHAPPEY, J.L. (2006/2) : "De la science de l'homme aux sciences humaines : enjeux politiques d'une configuration du savoir (1770-1808)", Revue d'Histoire des Sciences Humaines, Dossier : Naissance de la science sociale (1750-1855), 15, pp. 43-68. 
CHARLE, C., SCHRIEWER, J., WAGNER, P. (2004) : Transnational Intellectual networks : Form of Academic Knowledge and Search for Cultural Identities, Frankfurt/Main, Campus Verlag.

CLAUZADE, L. (2003) : Comte et Stuart Mill. Les enjeux de la psychologie, Revue d'histoire des sciences humaines, $\mathrm{n}^{\circ} 8$, pp. 41-56.

COMíN COMÍN, F. (1999) : La modestas realizaciones de la nueva política económica intervencionista de la Restauración, in Fuentes Quintana, E. (coord.) Economía y Economistas españoles, Madrid, vol.5. Las críticas a la economía clásica, Galaxia Quintana : Circulo de lectores, pp. 197-238.

DAMAMME, D. (1995) : "Entre science et politique. La première science sociale", Politix, Vol.8, 29, Premier Trimestre, 1995, pp 5-30.

DAMAMME, D. (1982), Histoire des sciences morales et politiques et leur enseignement des Lumières au scientisme. Instituer le corps politique, fabriquer une tête de peuple, Université de Paris 1, thèse de science politique.

DEL CAMPO, S. (2001) : Historia de la sociología española, Barcelona, Ariel.

DELMAS, C. (2006) : Instituer des savoirs d'Etat. L'Académie des sciences morales et politiques au XIX ${ }^{\mathrm{e}}$ siècle, Paris, L'Harmattan.

DESCOLA, P. (2005) : Par-delà nature et culture, Paris, Gallimard.

DIAZ, E. (1973) : La Filosofía social del krausismo español, Madrid, Cuadernos para el diálogo, Edicusa.

DIEGO GARCÍA (de), E. (2009) : 1857-2007. La Real Academia de Ciencias Morales y Políticas. Cultura y política en la España contemporánea, Madrid, Real Academia de Ciencias Morales y Políticas.

DIEZ DEL CORRAL, L. (1945), El liberalismo doctrinario, Madrid, Instituto de Estudios Políticos, 1945.

DUQUE RODRIGUEZ DE ARRELLANO, I., GÓMEZ BENITEZ, C. (2006) : “Los estudios de Joaquín Costa sobre "Derecho Consuetudinario y Economía Popular" en los orígenes de la sociología española ", en Dios de Dios (de), S., Infante Miguel-Motta, J. Ricardo Robledo Hernández, R., Torijano Pérez, E., Historia de la propriedad : costumbre y prescripción : IV Encuentro Interdisciplinar, Salamanca, 25-28 de mayo de 2004, Servicio de Estudios del Colegio de Registradores, pp. 497-568.

DURKHEIM, E., FAUCONNET, P. (1903) : "Sociologie et sciences sociales", La Revue Philosophique, 55, pp. 465-497.

EPSZTEIN, L. (1966) : L'économie et la morale. Aux début du capitalisme industriel en France et en Grande-Bretagne, Paris, Armand Colin, 1966.

FORMENT, E. (1998) : Historia de la filosofía tomista en la España contemporánea, Madrid, Ediciones Encuentro.

FOUCAULT (1966) : Les mots et les choses. Une archéologie des sciences humaines, Paris, Gallimard.

GIL CREMADES, J. J. (1969) : El reformismo español. Krausismo, escuela histórica, neotomismo, Barcelona, Ariel. 
GOLDMAN, L. The origins of British 'social science' : political Economy, Natural science and statistics, 1830-1835, The Historical Journal, Vol. 26, No.3 (Sep., 1983), pp. 587-616.

GÓMEZ OCHOA, F. (2003) : "Pero, ¿ hubo alguna vez once mil vírgenes ? El Partido Moderado y la conciliación liberal, 1833-1868", en Manuel Cortina (coord.), Las máscaras de la libertad : el liberalismo español, 1808-1950, Madrid, Marcial Pons, pp. 135-168.

GRIMER-SOLEM, E. (2003) : The Rise of Historical Economics and Social Reform in Germany, 1864- 1894, Oxford, Clarendon Press Monographs.

GROSSI, P. (1977) : Un altro modo di possedere. L'emersione di forme alternative di proprietà alla coscienza giuridica postunitaria, Milano, Giuffrè.

GUSDORF, G. (1978) Les sciences humaines et la pensée occidentale 8 : La conscience révolutionnaire, les idéologues, Paris, Payot, 1978.

GUILLO, D. (2000), Les figures de l'organisation. Sciences de la vie et sciences sociales au XIXe siècle, Paris, Presses universitaires de France.

HEILBRON J., MAGNUSSON, L., WITTROCK, B. (1998) : "The rise of the social sciences and the formation of modernity", in Heilbron, J., Magnusson, L., Wittrock, B. (eds), The social sciences and the formation of modernity. Conceptual change in context, 1750-1850, Dordrecht, The Netherlands Kluwer Academic publishers, pp. $1-33$.

HEILBRON, J. (2004) : "The rise of social sciences disciplines in France", European Journal of Social Sciences, XLII-129, pp. 145-157.

HEILBRON, J. (2006) : Naissance de la sociologie, Marseille, Agone.

HEILBRON, J., N. GUILHOT, N., JEANPIERRE, L. (2009/2) : « Vers une histoire transnationale des sciences sociales », Sociétés contemporaines, $\mathrm{n}^{\circ} 73$, p. 121-145.

HEREDIA SORIANO, A. (1982): Política docente y filosofía official en la España del siglo XIX : La era isabelina, 1833-1868, Salamanca, Universidad, Instituto de Ciencias de la Educación.

HERMIDA DE BLAS, F. (2001),"Manuel de la Revilla (1846-1881)", in Ramón Emilio Mandado Gutiérrez, Gerardo Bolado Ochoa (coord.),"La ciencia española” : estudios, Santander, Universidad de Cantábria, 2011, pp. 23-36

IGLESIAS DE USSEL, J. (2001) : "Severino Aznar: hombre de acción y sociólogo", en Salustiano del Campo, Historia de la sociología española, Barcelona, Ariel, pp. 101-128.

JEREZ MIR, R. (1980) : La introducción de la sociología en España : Manuel Sales y Ferré, una experiencia frustrada, Madrid, Ayuso.

JIMENEZ GARCÍA, A. (1986) : El krausismo y la Institucion Libre de Enseñanza, Madrid, Editorial Cincel.

KARSENTI, B. (2006) : Politique de l'esprit. Auguste Comte et la naissance de la science sociale, Paris, Hermann.

KELLEY, D.R. (1990) : The human measure. Social thought in the western legal tradition, Cambridge (Massachusetts), London (England), Harvard University Press.

KUPER, A. (1988) : The invention of primitive society. Transformation of an illusion. London, Routledge. 
LABORIER, P. (1999) : “«La bonne police”. Sciences camérales et pouvoir absolutiste dans les Etats allemands", Politix, vol. 12, n48, pp. 7-15.

LABORIER, P, NAPOLI, P, VOGEL, J., AUDREN, F., (2011) : Les sciences camérales : activités pratiques et dispositifs publics, Paris, Presses Universitaires de France.

LAFUENTE NIÑO, E. (1980) : "Sobre los orígenes de la psicología científica en España. El papel del movimiento krausista”, Estudios de Psicología, 1, pp. 138-147.

LETERRIER, S.A. (1995) : L'institution des sciences morales (1795-1850), Paris, L'Harmattan.

LINDENFELD, D. F. (1997) : The practical imagination. The german Sciences of State in the nineteenth Century, Chicago, The University of Chicago press.

LÓPEZ-OCÓN CABRERA, L. (2006) : “Ciencia y progreso durante la época bajoisabelina (1854-1868)", in Suárez Cortina, M. (ed.), La redención del pueblo : la cultura progresista en la España liberal, Santander, Publicaciones de la Universidad de Cantábria, pp. 315-346.

LLUCH MARTÍN, E., ARGEMÍ DE ABADAL, L. (2000) : "El krausismo económico sin institución libre : la influencia germaníca en España (1800-1860)", Sistema, revista de ciencias sociales, 157, pp. 3-18.

LLUCH MARTÍN, E., ARGEMÍ DE ABADAL, L. (2000) : La influencia alemana en España (1800-1860) desde el cameralismo tardío a Jakob, Krause y List, in Fuentes Quintana, E., Economía y economistas españoles, Tomo 4 (La economía clásica), Barcelona, Galaxía Gutemberg, pp. 451-482.

MALO GUILLÉN, J.L. (1999) : "La Real Academia de Ciencias Morales y Políticas ante el proceso de reforma sociales", en Enrique Fuentes Quintana (coord.), Economía y economistas españoles, Vol. 5, pp. 495-524.

MALO GUILLÉN, J.L. (2002) : "El krausismo en las ciencias sociales", en Herrero y Rodríguez de Miñon, M. y Scholz, J. M. (coord.), Las ciencias sociales y la modernización. La función de las academias, Madrid, Academia de ciencias morales y políticas, pp. 379-422.

MALO GUILLÉN, J. L. (2005) : El Krausismo económico, estudio introductorio, Real Academia de Ciencias Morales y Políticas, Madrid, pp. 26-27.

MARTÍN LÓPEZ, E., (2003) : "El Instituto de Reforma Sociales y los orígenes de la sociología en España", Revista del Ministerio de Trabajo y Asuntos sociales, $n^{\circ}$ IV, pp. 70-78

MOMIGLIANO, A. (1982) : "From Mommsen to Max Weber", History and Theory, Vol. 21 (Dec.), No.4, Beiheft 21 : New Paths of Classicism in the Nineteenth Century, pp. 16-32).

MONERERO PÉREZ, J.L. (2009), “La ideología del darwinismo social : La política de Herbert Spencer (I)”, Documentación Laboral, n87, 2009, pp. 11-81.

MONTERO, F. (1980) : "La polémica sobre el intervencionismo y la primera legislación obrera en España, 1890-1900. (Parte I) El debate académico", Revista de Trabajo, 59-60, $1980\left(3^{\circ}, 4^{\circ}\right.$ Trimestre), pp. 121-165. 
MONTERO, F. (1999) : "La critica católica de la economía clásica y el primer catolicismo social (sobre el impacto de "Rerum novarum" y la aportación de los católicos españoles al reformismo social" in Economía y economistas españoles, vol.5. Las críticas a la economía clásica, Madrid, Círculo de lectores: Galaxía Gutemberg, pp. 451-493.

MORAL RUIZ (del), J., PRO RUIZ, J., SUAREZ BILBAO, F. (2007) : Estado y Territorio en España, 1820-1930 : la formación del paisaje nacional, Madrid, Los libros de la Catarata.

MORAVIA, S. (1974) : Il pensiero degli Idéologues. Sienza e filosofía in Francia (17801815), Florence, La Nuova Italia.

NAPOLI, P. (2003) : Naissance de la police moderne. Pouvoir, normes, société, Paris, La Découverte.

NIETO BLANCO, C. (2011) "Ciencia y Krausismo. Gónzalez de Linares y Menéndez Pelayo", in Ramón Emilio Mandado Gutiérrez, Gerardo Bolado Ochoa (coord.),'La ciencia española" : estudios, Santander, Universidad de Cantábria, pp. 81-107.

NUÑEZ ENCABO, M. (1999) : "El centenario de la primera catedra de sociología" Sistema. Revista de Ciencias sociales 148, pp. 57-69.

NUÑEZ RUIZ, D. (1975) : La mentalidad positiva en España, desarrollo y crisis, Madrid, Tucar.

NUÑEZ RUIZ, D. (1969) : El darwinismo en España, Madrid, Editorial Castalia.

NUÑEZ RUIZ, D. (1979) : “La “cuestión social’ y la génesis de la Sociología”, Llull : Revista de la Sociedad española de Historia de las Ciencias y de las Técnicas, n³, pp. 29-36.

ORDEN JÍMÉNEZ, R.V. (1998) El sistema de la filosofía de Krause : génesis y desarollo del panenteísmo, Madrid, Universidad Pontificia Comillas.

ORTIZ, C. (1999) : "Ideas sobre el pueblo en el imaginario nacional español del 98” in Naranjo Orovio, C., Serrano Lacarra, C., Imágenes e imaginario nacionales en el ultramar español, Madrid, Consejo Superior de Investigaciones Científicas, Casa de Velázquez.

PALACIO MORENA, J.I. (1988) : La institucionalización de la reforma social en España (1883-1924). La Comisión y el Instituto de Reformas Sociales, Madrid, Centro de publicaciones, Ministerio de Trabajo y Seguridad Social.

PEEL, J. D.Y. (1992) : Herbert Spencer, the evolution of a sociologist, Aldershot Gregg revivals.

PELAYO, F. (1999) : Ciencia y creencia en España durante el siglo XIX. La palenontología en el debate sobre darwinismo, Madrid, Consejo Superior de Investigaciones Científicas.

PELLISTRANDI, B., (1997) Escribir la historia de la nación española : proyectos y herencia de la historiografía de Modesto Lafuente y Rafael Altamira, Investigaciones históricas : Época moderna y contemporánea, n¹7, pp. 137-160.

PÉREZ-DELGADO, E. (1996) : "Marcelino Arnaiz : primer testimonio del influjo de la universidad de Lovaina en la psicología española a finales del siglo XIX", in Saiz, M., Saiz D., Personajes para una historia de la psicología en España, Madrid, Ediciones Pirámides, Universitat Autònoma de Barcelona, pp. 243-252. 
PÉREZ PRENDES, J. M. (1999) : "Consideraciones sobre el influjo del krausismo en el pensamiento jurídico español”, in Pedro Alvarez Lázaro, Enrique M. Ureña (eds), La actualidad del Krausismo en su contexto europeo, Madrid, Editorial PerteluzUniversidad Pontificia Comillas : Fundación Duque de Soria.

PESET, M., PESET J.L., (1974) : La universidad española, (Siglo XVIII y XIX) : despotismo ilustrado y revolución liberal, Madrid, Taurus.

PESET, M., PESET J.L. (1992) : “Las universidades españolas del siglo XIX y las ciencias", Ayer, n'7, pp. 15-50.

PESET, M., GARMA, S., PEREZ GARZÓN, J.S., (1978) : Ciencia y enseñanza en la revolución burguesa, Madrid, Siglo veintiuno de españa editores.

PETIT, A. (2002), "Conflits et renouveau de la psychologie comtienne", in Bourdeau, M., Chazel, F., Auguste Comte et l'idée de science de l'homme, Paris, L'harmattan, pp. $85-130$.

PINO DIAZ (DEL), F. (1994) : "Concurso sobre derecho consuetudinario y economía popular de la Real Academia de Ciencias Morales y políticas", in Carmen Ortiz García, Luis Ángel Sánchez Gómez, Diccionario Histórico de la Antropología española, Madrid, Consejo Superior de Investigaciones Científicas, pp. 214-219.

PIQUERAS ARENAS, J.A. (1992) : La Revolución democrática (1868-1874). Cuestión social, colonialismo y grupos de presión, Madrid, Ministerio del Trabajo y Seguridad Social.

PRO RUIZ, J. (1998) : “La política en tiempos del Desastre”, in Pan-Montojo González, J.L. (coord.), Más se perdió en Cuba : España, 1898 y las crisis de fin de siglo, Madrid, Alianza editorial, pp. 151-260.

PUELLES BENÍTEZ (DE), M. (1995) : "Reflexiones sobre la formación del Estado liberal y la construcción del sistema educativo (1834-1857) ", in Vega Gil, L. (coord.), Moderantismo y educación en España. Estudios en torno a la ley Moyano, Zamora, Instituto de Estudios Zamoranos, Florián de Ocampo.

RAMÍREZ ARLANDI, J. (2007) : Siro García del Mazo, traductor"en vista" de Spencer : apuntes sobre la recepción y traducción de textos ensayísticos a finales del siglo XIX, in Juan Jesús Zaro Vera Traductores y traducción de textos ensayísticos a finales del siglo XIX (1835-1919), 2007, pp. 279-320.

RICHARD, E. (2008) : L'esprit des lois. Droit et sciences sociales à l'Académie royale des sciences morales et politiques d'Espagne (1857-1923), thèse, Université de Paris 1-Sorbonne.

ROMEO MATEO, M.C., (1998) : "Lenguaje y política del Nuevo liberalism : moderados y progresistas", Ayer, N²9, pp. 37-62.

SALA CATALA, J. (1987) : Ideología y ciencia biológica en España entre 1860-1881 : la difusión de un paradigma, Madrid, CSIC.

SANCHEZ GOMEZ, L.A., ORTIZ, C., (1994) : Diccionario histórico de la antropología española, Madrid, C.S.I.C.

SAVOYE, A. (1999) "Note sur l'implantation du mouvement leplaysien en Espagne (1880-1900)", Les Etudes sociales, vol.1err semestre, n¹29, pp. 31-40. 
SCHIERA, P. (1991), "Science and Politics" as a Political Factor : German and Italian Social Sciences in the Nineteenth Century", in Wagner, P., Vittrock, B., Richard P. Whitley (eds.) Discourses on Society : The Shaping of the Social Science Disciplines, Dordrecht, Netherlands, Kluwer Academic Publishers, pp. 93- 120.

SCHLANGER, J. (1995) : Les métaphores de l'organisme, Paris, L' Harmattan.

SERRANO GARCÍA, R. (2006) El progresismo laico y filodemocrático del Sexenio (1868-1874), in Suárez Cortina, M. (ed.), La redención del pueblo : la cultura progresista en la España liberal, Santander, Publicaciones de la Universidad de Cantábria, pp. 347-370.

SERRY, H. (2004/3) : "Saint Thomas sociologue ? Les enjeux cléricaux d'une sociologie catholique dans les années 1880-1920", Actes de la recherche en sciences sociales, 153 , pp. 28-40.

SIMÓ RUESCAS, J. (2004) : "La naturphilosophie en España. La recepción del evolucionismo eb el entorno de la tradición Krausista", Asclepio, Revista de historia de la medicina y de la ciencia,Vol. LVI-2, pp. 197-222.

SMITH, R. (1995) : The language of human nature, in Fox, C., Porter, R. Wokler, R., Inventing human sciences. Eighteenth -Century Domains, University of California Press.

STAUM, M. S. (1980): “The Class of Moral and Political Sciences, 1795-1803”, French Historical Studies, vol. 11, 3, pp. 371-397.

STEINER, P., (2008/1) : La tradition française de critique sociologique de l'Economie politique, Revue d'histoire des sciences humaines, pp. 64-84.

STOLLEIS, M. (2014) : Histoire du droit public en Allemagne, Vol. 2. 1800-1914, Paris, Dalloz.

SUÁREZ CORTINA, M. (2000) : "Reformismo Laico y "cuestión social” en la España de la Restauración” en Uría, J. Institucionismo y reforma social en España. El grupo de Oviedo, Madrid, Talasa, pp. 38-65.

TERMES, J. (2000) : Anarquismo y sindicalismo en España : La primera Internacional (1864-1881), Barcelona, Editorial Crítica.

TOMAS Y VALIENTE, F. (1989): Códigos y Constituciones, 1808-1978, Madrid, Alianza editorial.

TRAUTMANN WALLER, C. (coord.), Quand Berlin pensait les peuples. Anthropologie, ethnologie et psychologie (1850-1890), Paris, CNRS éditions, 2004.

TRIBE, K. (1984) : "Cameralism and the Science of Government", The Journal of Modern History, Vol. 56, 2, pp. 263-284.

UREÑA, E.M. (2009) "Sociedad, economía y educación en Krause, Schäffle y Giner", in Vazquez Romero, J. (coord.), Francisco Giner de los Ríos. Actualidad de un pensador krausista, Madrid, Marcial Pons, pp. 83-136

VATIN, F. (2005) : "A quoi rêvent les polypes ? Individuation et sociation d'Abraham Tremblay à Emile Durkheim", Trois essais sur la genèse de la pensée sociologique. Politique, épistémologie et cosmologie, Paris, La Découverte, pp. 123-217.

VATIN, F., (2006/3) : "Romantisme économique et philosophie de la misère en France dans les années 1820-1840”, Romantisme, N¹33, pp. 35-47. 
VELASCO MORENO, E. (2000) : "Nuevas instituciones de sociabilidad, las academias de finales del siglo XVII y comienzos del siglo XVIII", Cuadernos Dieciochista, 1, pp. 39-55.

VILLACORTA BAÑOS, F. (2003) : “Los ateneos liberales: política, cultura y sociabilidad intellectual”, Hispania, LXIII/2, núm 214, pp. 415-442.

VINCENT, J. (2007) :'Les sciences morales de la gloire à l'oubli? Savoir et politique en Europe au XIX ${ }^{\mathrm{e}}$ siècle", Revue pour l'histoire du CNRS, 18, automne 2007, pp. $38-43$.

VIÑAO FRAGO, A. (1982) : Política y educación en los orígenes de la España contemporánea. Examen especial de sus relaciones en la enseñanza secundaria, Madrid, Siglo XXI de España editores.

WAGNER, P. (1991) : «Science of Society lost : on the failure to establish sociology in Europe during the 'classical' period », in : Wagner P., Wittrock B., Whitley R. (dir.), Discourses on Society. The Shaping of the Social Science Disciplines, Dordrecht, Boston, London, Kluwer Academic publishers.

WAGNER, P., WITTROCK, B. (1991) State, institutions, and discourses : a comparative perspective on the structuration of the social sciences, en Wagner, P., Vittrock, B., Richard P. Whitley (eds.) Discourses on Society : The Shaping of the Social Science Disciplines, Dordrecht, Netherlands, Kluwer Academic Publishers, pp. 331-357.

WALKER, M. (Jun., 1978) :'The Social Categories of Eighteenth-Century German Jurists and Cameralists", The Journal of Modern History Vol 50, No.2 pp 234-25.

WAQUET, F. (2003), Parler comme un livre, L'oralité et le savoir (XVI ${ }^{\mathrm{e}}-\mathrm{XX}^{\mathrm{e}}$ siècles), Paris, Albin Michel.

WEULERSSE, G. (1910) : Le mouvement physiocratique en France de 1756 à 1770, Tome II, Paris, Felix Alcan.

WITTROCK, B., WAGNER, P., WOLLMANN, H. (1991) Social science and the modern state: policy knowledge and political institutions in Western Europe and the United States, in

WAGNER, P., WEISS, C. H., WITTROCK, B., WOLLMANN, H (eds), Social Sciences and modern States. National experiences and theoretical crossroads, pp. 28-85.

ZARCO, J. (1999) : "Notas sobre el Instituto de reformas sociales y las tres historias de la sociología española", Revista española de investigaciones sociológicas, 86, pp.129-156. 